\title{
The Effect of Non-Marine vs. Marine Sources of the Omega-3 Fatty Acids, DHA and EPA, on Serum Lipoproteins
}

\author{
Mary C. Rodavich \\ West Virginia University
}

Follow this and additional works at: https://researchrepository.wvu.edu/etd

\section{Recommended Citation}

Rodavich, Mary C., "The Effect of Non-Marine vs. Marine Sources of the Omega-3 Fatty Acids, DHA and EPA, on Serum Lipoproteins" (2013). Graduate Theses, Dissertations, and Problem Reports. 345.

https://researchrepository.wvu.edu/etd/345

This Thesis is protected by copyright and/or related rights. It has been brought to you by the The Research Repository @ WVU with permission from the rights-holder(s). You are free to use this Thesis in any way that is permitted by the copyright and related rights legislation that applies to your use. For other uses you must obtain permission from the rights-holder(s) directly, unless additional rights are indicated by a Creative Commons license in the record and/ or on the work itself. This Thesis has been accepted for inclusion in WVU Graduate Theses, Dissertations, and Problem Reports collection by an authorized administrator of The Research Repository @ WVU. For more information, please contact researchrepository@mail.wvu.edu. 


\title{
The Effect of Non-Marine vs. Marine Sources of the Omega-3 Fatty Acids, DHA and EPA, on Serum Lipoproteins
}

\author{
Mary C. Rodavich \\ Thesis submitted to the \\ Davis College of Agriculture, Natural Resources, and Design \\ at West Virginia University \\ in partial fulfillment of the requirements \\ for the degree of \\ Master of Science \\ in \\ Nutrition and Food Science
}

Kimberly M. Barnes, PhD, Chair

Janet C.L. Tou, PhD

K. Marie Krause, PhD

Division of Animal and Nutritional Sciences

West Virginia University

Morgantown, WV

2013

Keywords: omega-3 fatty acids, fish oil, algae oil, yeast oil, serum lipoproteins, gene expression, marine, non-marine

Copyright 2013 Mary C. Rodavich 


\section{ABSTRACT \\ The Effect of Non-Marine vs. Marine Sources of the Omega-3 Fatty Acids, DHA and EPA, on Serum Lipoproteins}

\section{Mary C. Rodavich}

Background: Fish oil (FO) is a marine source of n-3 fatty acids, eicosapentaenoic acid (EPA) and docosahexanaenoic acid (DHA), and has been shown to improve heart health.

Objective: The purpose of this study was to determine the cardiovascular effects of non-marine sources of n-3 fatty acids, algae oil (AO) and yeast oil (YO), as compared to fish oil (FO).

Methods: Male ICR mice ( 8 wk old, $n=100)$ were randomly assigned to dietary treatment groups: soy oil (SO; 0 g/kg DHA or EPA), FO (7.03 g/kg DHA + $12.64 \mathrm{~g} / \mathrm{kg}$ EPA), AO (7.03 $\mathrm{g} / \mathrm{kg}$ DHA $+0.13 \mathrm{~g} / \mathrm{kg}$ EPA), YO (0.018 g/ $\mathrm{kg}$ DHA + $12.64 \mathrm{~g} / \mathrm{kg}$ EPA $)$, or AO+YO (7.05 g/ $\mathrm{kg}$ $\mathrm{DHA}+12.77 \mathrm{~g} / \mathrm{kg}$ EPA) for 2 or 4 wks. Serum triglycerides (TG), total cholesterol (TC), and HDL-cholesterol (HDLC) were measured and non-HDL cholesterol (NHDLC) was calculated. Liver DHA and EPA concentration were determined. The liver mRNA expression was determined by real time RT-PCR for the following genes: apolipoprotein B100 (ApoB100), acylCoA:cholesterol acyltransferase (ACAT), diglyceride acyltransferase (DGAT), low-density lipoprotein receptor (LDLR), and 3-hydroxy-3-methyl-glutaryl-CoA reductase (HMGCR). P < 0.05 is considered significant.

Results: The FO diet lowered all fractions of serum lipids and was the only diet to reduce TG. YO, alone and in combination with AO, reduced TC and NHDLC similar to FO at 4 wks. At both time points, FO-fed mice had significantly greater EPA and DHA incorporation into the liver than all other diet treatments. At both time points, SO-fed mice had significantly greater hepatic arachidonic acid (C20:4) concentrations than all other diet treatments. At both time points, FO-fed mice had significantly greater n-3 to n-6 ratios compared to all other diet treatments. There were no significant differences between any of the diet treatments at any time points in hepatic mRNA expression of ApoB100, ACAT, DGAT, and LDLR. However, at both time points the FO-fed mice had significantly down-regulated HMGCR expression compared to the SO-fed mice.

Conclusion: In conclusion, it appears that FO supplementation may be more beneficial for cardiovascular health due to its ability to decrease serum lipids and TGs, incorporate EPA and DHA into the liver, obtain a greater n-3 to n-6 ratio, and lower hepatic HMGCR mRNA expression. 


\section{ACKNOWLEDGEMENTS}

I would like to thank the following individuals for their time, knowledge, and enduring support throughout this endeavor.

\section{Thesis Committee Members}

Kimberly M. Barnes, PhD, Chair

Janet C.L Tou, PhD

Marie Krause, $\mathrm{PhD}$

\section{Davis College - West Virginia University}

Siri Ippagunta, PhD

John Ketz

Melissa Olfert, DrPH, MS, RD, LD

All other faculty

Fellow peers and dietetic interns

\section{My Family \& Friends}

My parents - Laura and Ted Rodavich

My siblings - Brian, Kelly, and Jane Rodavich

My pets - Sidney, Kitty, and Buddy 


\section{TABLE OF CONTENTS}

\section{Page Number}

ABSTRACT

ACKNOWLEDGEMENTS

TABLE OF CONTENTS

CHAPTER 1: REVIEW OF LITERATURE 1

INTRODUCTION 2

I. LIPID AND LIPOPROTEIN METABOLISM 3

II. MARINE VS. NON-MARINE SOURCES OF OMEGA-3 5 SUPPLEMENTATION

A. Fish Oil Supplementation 6

B. EPA versus DHA-rich Fish Oil Supplementation 9

C. Algae Oil Supplementation $\quad 11$

D. Yeast Oil Supplementation 13

CHAPTER 2: THE EFFECT OF NON-MARINE VS. MARINE SOURCES 17

OF THE OMEGA-3 FATTY ACIDS, DHA AND EPA, ON SERUM LIPOPROTEINS

$\begin{array}{llr} & \text { ABSTRACT } & 18 \\ \text { I. } & \text { INTRODUCTION } & 19\end{array}$

II. MATERIALS AND METHODS 20

A. Experimental Diets 20

B. Animal Feeding Study 21

C. Fatty Acid Analysis $\quad 22$

D. Serum Lipid and Lipoprotein Measurements 22

E. RNA Isolation and Gene Expression 23

F. Statistical Analysis 23

III. RESULTS $\quad 24$

A. Feed Intake, Body Weight, and Tissue Weight 24

B. Serum Lipids and Lipoproteins 24

C. Fatty Acid Analysis of the Liver 25

D. mRNA Relative Expression of Selected Genes in the Liver 27

$\begin{array}{ll}\text { IV. DISCUSSION } & 27\end{array}$

V. REFERENCES 50

LIST OF FIGURES $\quad$ iii

LIST OF TABLES $\quad$ iv 


\section{LIST OF FIGURES}

Figure 1: Chemical structures of DHA, EPA, and ARA

$\underline{\text { Page Number }}$

Figure 2: Cholesterol Synthesis Pathway

Figure 3: Relative Liver Weights

Figure 4: Effect of Dietary Treatment on Serum Lipids

A. Effects of Diet on Serum Total Cholesterol

43

B. Effects of Diet on Serum Non-HDL Cholesterol

43

C. Effects of Diet on Serum HDL Cholesterol

44

D. Effects of Diet on Serum Triglycerides

44

Figure 5: Effect of Dietary Treatment on Relative mRNA Gene Expression in the Liver 48
A. Effects of Diet on ACAT Expression
48

B. Effects of Diet on ApoB100 Expression

48

C. Effects of Diet on DGAT Expression

49

D. Effects of Diet on LDL Receptor Expression

49

E. Effects of Diet on HMG-CoA Reductase Expression

49 


\section{LIST OF TABLES}

Page Number

Table 1: Types of Marine vs. Non-Marine Sources of Omega-3 Fatty Acids

Table 2: Ingredient Composition of the Experimental Diets Fed to Mice 38

Table 3: Dietary Fatty Acid Composition of the Oils 39

Table 4: Details of Primers Used for Real-time Reverse-Transcription PCR 40

Table 5: Effect of Dietary Treatment on Feed Intake, Body Weight, and Tissue Weight

Table 6: Effect of Dietary Treatment on the Fatty Acid Profile of the Liver 45 
CHAPTER 1

REVIEW OF LITERATURE 


\section{INTRODUCTION}

There has been a vast amount of scientific and medical interest in the beneficial effects of long chain omega-3 polyunsaturated fatty acids (n-3 LC-PUFAs) on the risk for cardiovascular disease (CVD). The n-3 LC-PUFAs, eicosapentaenoic acid (EPA; 20:5n-3) and docosahexaenoic acid (DHA; 22:6n-3), have been associated with a decreased risk of CVD incidence and mortality (1). This is significant in the western world because CVD is the leading cause of death in the United States (2). There are several proposed mechanisms whereby n-3 LCPUFAs reduce the risk of heart disease. Omega-3 fatty acids have been found to decrease plasma triglyceride levels, mildly lower blood pressure, and to have anti-inflammatory effects (1). Omega-3's are thought to lower triglyceride (TG) levels by decreasing endogenous VLDL secretion by the liver because they may not be the preferred substrate of the enzyme, diacylglycerol O-acyltransferase (DGAT), or omega-3 PUFAs may alter transcription factors that control lipogenesis (3).

Consumption of a high ratio of omega- 6 to omega-3 fatty acids has been shown to be proinflammatory and increase the risk of CVD. This is because omega- 6 and omega- 3 fatty acid metabolism compete for the same rate limiting enzyme ( $\Delta 6$-desaturase) (4). The precursor for omega-3 PUFA is alpha-linolenic acid (ALA) and is found primarily in plant-based foods and oils such as rapeseed and soybean oils, green leafy vegetables, and nuts. ALA is converted to EPA by the introduction of a double bond by $\Delta 6$-desaturase to stearidonic acid (18:4); this is the rate limiting step of the omega-3 pathway. Then, two carbons are added by elongase, followed by the action of $\Delta 5$-desaturase to form EPA (20:5). The next step is the conversion of EPA to DHA. This involves the addition of two carbons by elongase followed by the addition of another two carbons by elongase, resulting in tetracosapentaenoic acid (24:5). The next step is 
desaturation by $\Delta 6$-desaturase to form a double bond, followed by $\beta$-oxidation which loses two carbons in order to form DHA (22:6). The chemical structures of EPA and DHA are presented in Figure 1. The conversion of ALA to EPA and ALA to DHA is not very efficient by the human body. The body only converts between approximately $8-10 \%$ of ALA to EPA (with conversion generally higher in women, thought to be due to estrogen levels) and $0.05 \%$ to $4 \%$ of ALA to DHA (5). Therefore, it is more efficient to consume those PUFA's as whole sources of EPA and DHA rather than through ALA.

The n-3 LC-PUFAs are most commonly consumed through sources of marine origin, such as fatty, cold water fish. Common marine sources of omega-3 fatty acids include sardines in sardine oil, Atlantic mackerel, herring, Chinook salmon, anchovies, and Atlantic salmon. Nonmarine or alternative sources of n-3 LC-PUFAs include microalgae or algae and yeast (4). There is a vast amount of evidence supporting the benefits of fish oil, which is high in both EPA and DHA, on CVD risk factors. However, the specific contributions of EPA and DHA to these benefits are mostly unknown. The objective of this paper is to examine the literature on nonmarine and marine sources of EPA and/or DHA and its effects on body weight, lipids, and lipoproteins.

\section{LIPID AND LIPOPROTEIN METABOLISM}

Lipoproteins are lipids bound to proteins and transported through the blood. Varying amounts of triglyceride, cholesterol, phospholipid, and protein determines the class or type of lipoprotein. These lipoproteins are very-low density lipoprotein (VLDL), low-density lipoprotein (LDL), and high density lipoprotein (HDL). Clinically, total cholesterol measures cholesterol attached on all lipoprotein subfractions (VLDL, LDL, and HDL). 
High TG levels have been shown to be associated with increased CVD risk (1). TG is an ester formed from glycerol and three fatty acids and is the major storage form of lipids and the primary lipid form consumed in the diet. Diglyceride acyltransferase (DGAT) catalyzes the addition of a fatty acyl chain to a diacylglycerol, which is the rate-limiting step in TG synthesis (6).

Population studies have shown that high cholesterol levels are associated with an increased risk of CVD, stroke, and death. Human studies have shown that a $10 \%$ reduction in total cholesterol decreases the risk for CVD by $30 \%$ (4). Dietary cholesterol can be consumed through the diet or cholesterol can be produced from acetyl CoA by most tissues in the body via de novo cholesterol synthesis. However, the liver is the major site of cholesterol synthesis. There are at least 26 steps in the synthesis of cholesterol, refer to Figure 2 (7). HMG-CoA reductase is the rate limiting enzyme in cholesterol synthesis, reducing 3-hydroxy-3-methylgluaryl CoA (HMG-CoA) to mevalonate (6). HMG-CoA reductase is located in the smooth endoplasmic reticulum and is an important point for the regulation of cholesterol synthesis. HMG-CoA reductase activity is mediated by phosphorylation in response to glucagon (decreases cholesterol synthesis) and dephosphorylation in response to insulin (promoting cholesterol synthesis), respectively (8). Cholesterol biosynthesis indirectly requires the transcription factors, sterol regulatory element-binding proteins (SREBPs). There are three SREBP isoforms: SREBP1a, SREBP1c, and SREBP2. The predominant isoform in rodent and mammalian and rodent livers is SREBP1c. SREBP1c induces the transcription of a variety of genes involved in lipogenesis and SREBP2 is involved in cholesterol synthesis $(9,10)$.

LDL is the primary carrier of cholesterol in the blood, from which $60 \%$ is taken up by LDL receptors in the liver, adrenals, and various other tissues. The number and activity of LDL 
receptors is a determinant of the level of LDL-C in the blood (6). When LDL binds to its LDL receptor, endocytosis is initiated and the LDL as well as the receptor are taken into the cell (known as receptor-mediated endocytosis). The LDL receptors then return to the surface of the

cell and the cholesteryl esters are hydrolyzed, thus releasing cholesterol and fatty acids into the cytosol (8).

ACAT (acyl CoA: cholesteryl acyl transferase) is located in the endoplasmic reticulum and forms cholesterol esters from cholesterol by transferring a fatty acid from coenzyme A to the hydroxyl group of cholesterol (6). Cholesteryl esters are either stored in the liver or transported by lipoproteins to other tissues throughout the body. High levels of ACAT signal cholesterol esterification (8). Lecithin:cholesterol acyltransferase (LCAT) forms cholesteryl esters from free cholesterol and lecithin, which allows a newly formed HDL precursor particle to mature to a full HDL lipoprotein. These cholesterol esters are then transported to the liver bound to HDL, hydroylzed by cholesteryl esterase, and excreted in the bile. Because HDL-C is the major component of this process, known as reverse cholesterol transport, high HDL-C levels are associated with a decreased risk of CVD. The release of cholesterol esters also decreases HMGCoA reductase activity, increases ACAT activity, and decreases the number of LDL receptors to reduce the uptake of cholesterol from the blood.

These lipoprotein factors are influenced by n-3 LC-PUFAs. This paper will review the effect of different sources of n-3 LC-PUFAs on these factors starting with the most popular source, fish oil, followed by algae oil and yeast oil.

\section{MARINE VS. NON-MARINE SOURCES OF OMEGA-3 SUPPLEMENTATION}




\section{A. Fish Oil Supplementation}

There is a vast amount of scientific evidence from animal and human studies that have shown the beneficial effects of fish oil consumption and/or supplementation on cardiovascular health. It is well established in the literature that fish and fish oil consumption at 1-2 g/day have been shown to decrease the risk of CVD. The general recommendation is $0.3-0.5 \mathrm{~g}$ from EPA and DHA and 0.8-1.1 g ALA (1). A list of the types of marine and non-marine sources of omega3 fatty acids are presented in Table 1 .

As a marine source, fish oil contains high concentrations of both EPA and DHA. In a meta-analysis by Konig et al., eight studies were analyzed to determine the relative risk of fish consumption on non-fatal myocardial infarction (MI) and CVD mortality. After relative risks were averaged and weighted, results found that consumption of fish, even in small quantities, by individuals that had no pre-existing CVD was associated with a $17 \%$ reduction in CVD risk. Also, a 3.9\% reduction in risk was also associated with each additional serving of fish per week (11).

Rokling-Andersen et al. studied the effects of marine omega-3 fatty acids on 20 male Wistar rats for 7 weeks. The rats were randomly assigned into two groups, ten rats per group. One group was fed $19.5 \%$ lard and the other was fed an omega-3 rich diet containing $10.4 \%$ Triomar (a fish oil consisting of 30\% EPA and 18\% DHA) and 9.1\% lard. The authors measured weight gain, plasma lipid concentration, the expression of various genes, and visceral and adipose tissue using magnetic resonance imaging (MRI) and dissection. Results showed that the fish oil group had significantly lower blood lipid concentration. TG were 56\% lower $(\mathrm{p}<0.001)$, phospholipids were $41 \%$ lower $(\mathrm{p}<0.001)$, and total cholesterol was $40 \%(\mathrm{p}=0.05)$ lower than the 
lard group. Magnetic resonance imaging showed that adipose tissue was also significantly decreased in the fish oil group. Visceral adipose depots (mesenteric, perirenal and epididymal) were decreased 35\% ( $\mathrm{p}<0.05), 44 \%(\mathrm{P}<0.01)$ and $32 \%(\mathrm{P}<0.01)$ respectively compared to the lard group. DGAT mRNA expression was also significantly reduced $(\mathrm{P}<0.05)$ in the perirenal and epididymal fat depots in the fish oil group. Therefore, fish oil supplementation in male rats showed improved lipoprotein levels and slowed weight gain (12). However, discrepancies between MRI and dissection weight and volume of mesenteric fat may indicate the difficulty of these types of measurements.

Fickova et al. also studied the effects of omega-3 supplementation on male Wistar rats. However, in comparison to the 7-week study by Rokling-Andersen et al., this was a very short term study conducted over only one week. Rats were randomized into one of two diet treatments consisting of 40.7\% lipid content; sunflower oil (omega-6 PUFA) or fish oil (Max EPA, omega-3 PUFA). The fish oil diet consisted of 16.3\% EPA 9.3\% DHA. Measurements included epididymal adipocyte size and plasma lipoproteins. Results found that the fish oil group gained significantly less weight $(21.3 \pm 1.1 \mathrm{~g}$ vs $29.1 \pm 1.3 \mathrm{~g}, \mathrm{p}<0.001)$, had significantly smaller adipose tissue mass $(1.97 \pm 0.1$ vs $2.45 \pm 0.1 \mathrm{~g}, \mathrm{p}<0.02)$ and had significantly smaller adipocytes $(67.0 \pm$ $2.4 \mu \mathrm{m}$ vs $73.6 \pm 1.7 \mu \mathrm{m}, \mathrm{p}<0.05)$ than the omega- 6 group. The fish oil group also had significantly lower serum TG $(1.26 \pm 0.1 \mathrm{mmol} / \mathrm{L}$ vs $1.70 \pm 0.1 \mathrm{mmol} / \mathrm{L}, \mathrm{p}<0.005)$, total cholesterol $(0.81 \pm 0.06 \mathrm{mmol} / \mathrm{L}$ vs $1.45 \pm 0.09 \mathrm{mmol} / \mathrm{L}, \mathrm{p}<0.005)$, and cholesterol esters $(0.45 \pm$ 0.04 vs $0.91 \mathrm{mmol} / \mathrm{L} \pm 0.07 \mathrm{mmol} / \mathrm{L}, \mathrm{p}<0.02$ ) than the omega- 6 PUFA group. The results of this study support the benefits of fish oil on weight gain and improved lipoprotein levels. However, the diets were very high in lipid content (40.7\%) and may have been a contributing factor to the results of supplementation over such a short period of time of only one week (13). 
In a human study, 65 subjects ( 24 men and 41 women) were randomized into one of four treatment groups, fish oil (FO), fish oil plus exercise (FOX), soy oil (SO, control), soy oil plus exercise (SOX). Participants consumed 6 capsules per day of either soy oil or fish oil (tuna source) for 12 weeks. One fish oil capsule contained 26\% DHA and 6\% EPA in each 1-g capsule. The exercise regimen consisted of running or walking 3 times/week for 45 minutes at $75 \%$ of their age-adjusted maximum heart rate. Results found that this modest exercise intervention did not produce any significant effects. Fish oil supplementation, however, significantly reduced TG by $14 \%(\mathrm{p}<0.05)$ and significantly increased HDL-C by $10 \%(\mathrm{p}<0.05)$ from baseline compared to the SO group. DEXA analysis found fat mass was significantly reduced in both the FO ( $\mathrm{p}=0.043)$ and FOX ( $\mathrm{p}=0.005)$ groups (14). Therefore, evidence shows that fish oil supplementation in human studies improved CVD lipid risk factors as well as decreases body fat.

There are some safety considerations with the consumption of fish and/or fish oil supplements. Fresh water and ocean fish may have levels of methyl-mercury, polychlorinated biphenyls (PCBs), dioxins, and other environmental contaminants (1). These levels become more concentrated in the marine food chain, with greater concentrations in the larger, dominant, older, and more predatory fish. Contaminants can also accumulate to higher levels in individuals who consume fish on a frequent basis. The Federal Drug Administration (FDA) concluded that healthy individuals (other than pregnant women) can consume up to $7 \mathrm{oz}$. of fish per week with mercury levels averaging $1 \mathrm{ppm}$ and $14 \mathrm{oz}$ per week of fish per week with mercury levels averaging $0.5 \mathrm{ppm}$. Higher mercury levels (1 ppm) are found in shark, swordfish, king mackerel, and tilefish and lower levels $(0.5 \mathrm{ppm})$ are found in fresh tuna, orange roughy, marlin, and red snapper (1). Therefore, there are several benefits to fish consumption in terms of high EPA and 
DHA content. However, there are some safety considerations that are necessary in choosing marine sources of n-3 LC-PUFAs, which may be one of many reasons an individual would choose a non-marine source. Lastly, an individual may choose not to consume a fish oil supplement due to following a vegan diet or a vegetarian diet with the exclusion of fish.

\section{B. EPA versus DHA-rich Fish Oil Supplementation}

There have also been several studies examining the effects of purified EPA and DHA provided as fish oil ethyl esters. Whereas, algae oil and yeast oil examine the effects of DHA and EPA alone from non-marine sources, fish oil ethyl esters study the effects of DHA and EPA alone from marine sources. These studies are of importance in order to observe any differences in EPA and DHA supplementation on serum lipids.

Mori et al. studied the independent effects of EPA and DHA on serum lipids and body weight on 59 overweight, mildly hyperlipidemic men. Participants were randomly assigned by age and BMI to receive one of three diets, 4 g/day of purified EPA ethyl ester, DHA ethyl ester, or olive oil ethyl ester (placebo), for six weeks. Throughout the six weeks, subjects were instructed to maintain their usual diets, alcohol intakes, physical activity, and to not make any lifestyle changes. Measurements included serum total cholesterol, TG, LDL-C, LDL particle size, and HDL-C. Results found that neither EPA nor DHA significantly decreased serum total cholesterol levels. Fasting serum TG decreased significantly by $18.4 \%$ in the EPA group $(\mathrm{p}=0.012)$ and by $20 \%$ in the DHA group $(\mathrm{p}=0.003)$ compared to placebo. Serum LDL-C increased significantly by $8 \%$ in the DHA group $(\mathrm{p}=0.019)$ and also significantly increased LDL particle size $(0.25 \pm 0.08 \mathrm{~nm}, \mathrm{p}=0.002)$, but there were no significant effects in the EPA group. The authors attribute the increased LDL-C levels with DHA supplementation because omega-3 
fats reduce VLDL synthesis and/or secretion. This results in smaller VLDL particles, which are more readily converted to LDL. DHA supplementation also increased LDL particle size, which can be contributable to decreased CVD risk and may be a more favorable finding. There were no significant changes in HDL-C, but the EPA group experienced a 3\% decrease in HDL-C whereas the DHA group experienced a 3\% increase in HDL-C. Therefore, this study found that both purified forms of EPA and DHA reduce serum TG, but have differential effects on LDL-C and HDL-C (15).

In another study on purified EPA and DHA ethyl esters, Grimsgaard et al. randomly assigned 234 healthy men to one of three diet treatments. Subjects received dietary supplements as capsules of either $4 \mathrm{~g}$ of $95 \%$ EPA ethyl ester/day, $4 \mathrm{~g}$ of $90 \%$ DHA ethyl esterday, or $4 \mathrm{~g} /$ day of corn oil as the placebo group for seven weeks. Measurements included body weight, total cholesterol, LDL-C, apolipoprotein B, and total cholesterol:HDL-C ratio. Results showed there were no differences in body weight or apolipoprotein B concentrations after the intervention between any of the groups. Both EPA and DHA groups had significantly reduced TG levels compared to placebo ( $21 \%$ and $26 \%$, respectively, $\mathrm{p}=0.0001)$. However, the difference between the DHA and EPA groups was not significant $(\mathrm{p}=0.14)$. In the EPA group, total cholesterol decreased significantly by $0.14 \mathrm{mmol} / \mathrm{L}(\mathrm{p}<0.05)$ from baseline. This decrease was significant compared to the DHA group and placebo group ( $\mathrm{p}=0.04$ and $\mathrm{p}=0.004$, respectively). In the DHA group, HDL-C significantly increased by $0.06 \mathrm{mmol} / \mathrm{L}(\mathrm{p}<0.001)$ from baseline. This increase was significantly different from both EPA and placebo groups $(p=0.009$ and $p=0.0005$, respectively). Also, both EPA and DHA groups had significantly decreased total cholesterol:HDL ratios compared to placebo ( $\mathrm{p}=0.007$ and $\mathrm{p}=0.0006$, respectively). This study agreed with much of the literature that both EPA and DHA lower TG concentrations, but this is 
one of the first to show a more pronounced effect in DHA supplementation. This study also observed differential effects of EPA and DHA on total cholesterol and HDL-C (16).

Arai et al. studied the effects of EPA or DHA-rich fish oil on lipid metabolism of 20 female KK mice (aged 5 weeks). Mice were randomized into one of four diet treatments consisting of $25 \%$ lipid for 8 weeks: either lard/safflower oil (Lard/SO, control), EPA-rich fish oil (20\% EPA and 13\% DHA), or DHA-rich fish oil (7\% EPA and 24\% DHA). Results showed that weight gain was significantly lower in both the EPA and DHA-rich fish oil groups compared to the Lard/SO group ( $\mathrm{p}<0.05)$. There was no significant difference between the fish oil groups. Liver weight was also significantly less in both EPA and DHA groups than the Lard/SO group $(1.36 \pm 0.14 \mathrm{~g}$ and $1.70 \pm 0.29 \mathrm{~g}$, respectively, $\mathrm{p}<0.05)$. White adipose tissue (WAT) weight was also significantly decreased in both the EPA and DHA groups compared to the control, with a greater reduction in the EPA group compared to the DHA group $(3.02 \pm 0.16 \mathrm{~g}$ vs. $3.64 \pm 0.33 \mathrm{~g}$, $\mathrm{p}<0.05)$. Contrary to many other studies, there was no difference in serum TG between the groups. Total cholesterol decreased significantly for both EPA and DHA groups compared to the control group $(53 \pm 4 \mathrm{mg} / \mathrm{dL}$ and $73 \pm 12 \mathrm{mg} / \mathrm{dL}$, respectively, $\mathrm{p}<0.05)$. In the EPA and DHA groups, there were significant decreases $(\mathrm{p}<0.05)$ in mRNA levels of HMG-CoA reductase (79\% and 53\%, respectively) and LDL receptors (67\% and 48\%, respectively). Thus, this study showed that both EPA and DHA-rich fish oils are successful at decreasing weight gain, body fat, and improving serum lipids in mice, however EPA showed more pronounced and beneficial effects. Also, the authors used a very small sample size, with only five mice per diet. A larger number of subjects could have increased the reliability of this study (17).

\section{Algae Oil Supplementation}


Non-marine or non-fish derived algae oil is composed of high DHA concentrations, with low EPA concentrations (18). Because algal DHA is grown in the laboratory, it is essentially free of contaminants typically found in ocean fish, such as methyl-mercury, dioxins, and polychlorinated biphenyls. Algae oil is also being used extensively as a food additive. In a metaanalysis of fifteen human studies, supplementation of 1-2 $\mathrm{g}$ of non-fish derived algae oil decreased TG $15-20 \%$ compared to baseline levels $\left(r^{2}=0.25, p<0.05\right)$. Algae oil has also been shown to significantly increase HDL-C levels and decrease LDL-C levels from baseline (18). Therefore, it is important to study the effects of algae oil supplementation on cardiovascular risk factors.

Two recent studies at West Virginia University compared the effects of fish oil or nonmarine algae oil on male ICR mice for two or four weeks. In the first study, the mice (aged 10 weeks) were randomized by weight into one of seven diets consisting of $12 \%$ lipid; a soy oil diet that contained no DHA (control), $5 \mathrm{~g} / \mathrm{kg}$ or $10 \mathrm{~g} / \mathrm{kg}$ DHA from FO (FO-5 and FO-10), $5 \mathrm{~g} / \mathrm{kg}$ or $10 \mathrm{~g} / \mathrm{kg}$ DHA from AO (AO-5 or AO-10), or $5 \mathrm{~g} / \mathrm{kg}$ or $10 \mathrm{~g} / \mathrm{kg}$ from an algal biomass (AB-5 and AB-10). Results found at two weeks, only FO-10 mice had significantly reduced TG, total cholesterol, and LDL-C. At four weeks, FO-5 and AO-10 mice had significantly lower serum TG, total cholesterol, and LDL-C ( $\mathrm{p}<0.01)$. At four weeks, there were no significant differences in body weight between the groups, but FO fed mice tended to be leaner than AO fed mice $(\mathrm{p}=0.06)$. Therefore, algae oil was not as effective as fish oil at reducing body fat, serum TG, and total cholesterol in mice (19).

In a second similar study, male ICR mice (aged 9 weeks) were fed either a fish oil or algae oil diet consisting of $12 \%$ lipid for 2 or 4 weeks. Mice were randomized by weight into one of five diets: $0 \mathrm{~g} / \mathrm{kg}$ DHA (SO), $10 \mathrm{~g} / \mathrm{kg}$ DHA (FO or AO-10), $20 \mathrm{~g} / \mathrm{kg}$ DHA (AO-20), 35 
$\mathrm{g} / \mathrm{kg}$ DHA (AO-35), or $50 \mathrm{~g} / \mathrm{kg}$ DHA (AO-50). Results found that at two weeks, the FO-fed mice and all AO-fed mice had significantly lower serum TG and total cholesterol levels $(\mathrm{p}<0.05)$. At four weeks, however, only FO-fed mice and higher doses of AO-fed mice (AO-35, AO-50) significantly reduced total cholesterol $(\mathrm{p}<0.001)$. Therefore, algae sources were less effective than fish oil at reducing body fat, serum TG, and total cholesterol in mice. This may be due to the fact that greater doses of algae oil DHA concentrations were required in order to obtain equal liver and adipose tissue DHA concentrations as mice fed the fish oil. Also, algae oil only reduced serum TG and total cholesterol levels at doses that resulted in more than four times the adipose tissue DHA concentration (20).

Conquer and Holub compared algae oil supplementation to placebo (corn oil) in 12 male and 12 female vegetarians for 6 weeks. The algae oil contained 39\% DHA (no EPA was detected). Measurements at week 3 and week 6 included total cholesterol, LDL-C, HDL-C, TG, total cholesterol:HDL ratio, and LDL:HDL ratio. Results showed that there were no significant differences between groups in total cholesterol and LDL-C levels. However, the algae oil group had significant decreases $(\mathrm{p}<0.05)$ in TG levels at week 3 and week $6(22 \%$ and $16 \%$, respectively), and showed significant decreases $(\mathrm{p}<0.05)$ in total cholesterol:HDL ratio and LDL:HDL ratio (16\% and 22\%, respectively). These ratios are better predictors of CVD compared to total cholesterol and LDL-C levels alone (21). Therefore, algal oil supplementation was beneficial, but no direct comparison to fish oil was made.

\section{Yeast Oil Supplementation}

Non-marine derived yeast oil is comprised mainly of high EPA concentrations, with very little DHA concentrations. Yeast oil (YO) is new on the market and little research has been 
conducted on this particular PUFA source. Yeast oil is of scientific interest because it is important to examine the effects of a new vegetarian source of EPA on body weight and serum lipids. Only two studies have been published on the effects of YO on rats for 28 days and 90 days. YO is derived from a strain of yeast called Yarrowia lipolytica, which was modified to produce high EPA levels. The oil is comprised of 34-60\% EPA that was produced through a multi-step fermentation process.

In a 28-day toxicity study of yeast oil, male and female Sprague-Dawley rats (aged 7 weeks) were randomized into and fed one of five diets by oral gavage. Fifteen rats each were randomized into one of five diets; olive oil (control), low EPA YO (325 mg/kg bw), medium EPA YO (650 mg/kg bw), high EPA YO (976 mg/kg bw), and a fish oil diet (from sardines and anchovies, $513 \mathrm{mg} / \mathrm{kg}$ EPA). Results found that liver weight significantly increased in both males and females in the medium EPA, high EPA, and fish oil groups $(\mathrm{p}<0.05)$. There were no significant changes in body weight in any of the groups and results indicated no adverse toxicological effects (22).

In a 90-day toxicity study of yeast oil, 20 male and 20 female Sprague-Dawley rats were randomized into and fed one of five diets and fed by oral gavage. The dietary treatment groups were olive oil (control), low EPA YO (98 mg/kg), medium EPA YO (488 mg/kg EPA), high EPA YO (976 mg/kg EPA), and a fish oil diet (from sardines and anchovies, $513 \mathrm{mg} / \mathrm{kg} \mathrm{EPA}$ ). Results showed no differences between groups on body weight or body weight gain. In males, total cholesterol was significantly less $(\mathrm{p}<0.05)$ at all times points in the medium EPA group (79$87 \%$ of control) and high EPA groups (62-72\% of control). Non-HDL was significantly less $(\mathrm{p}<0.05)$ in the medium EPA group $(72-81 \%$ of control) and high EPA group $(51-60 \%$ of control). In females, total cholesterol was also significantly reduced at every time point in the 
medium EPA group (82-85\% of control) and high EPA group (51-60\% of control). Non-HDL was significantly lower in the medium EPA group (74-78\% of control) and high EPA group (60$70 \%$ of control). However, liver weights were significantly increased $(\mathrm{p}<0.05)$ in males in the high EPA group as well as in females in the medium and high EPA groups. The authors reported pale livers during necropsy in males, but state the increase in liver has been reported in similar studies of rats given similar doses of omega-3 fatty acids (EPA and/or DHA). Also, HDL-C was significantly reduced $(\mathrm{p}<0.05)$ in males in the high EPA YO group $(76-81 \%$ of control) and the FO groups (76-78\% of control) at the 3 and 7 week time points, but there was no significant difference in HDL-C at the end of the 90-day study. There were no reductions in HDL-C in female rats.

Overall, the authors concluded that the yeast oil produced little adverse effects and no toxicity effects. There were also more pronounced effects on males compared to females. Also, higher dosages of YO were required in order to find significant effects on blood lipid levels. In addition, the maximum recommended dose of EPA and DHA is $2 \mathrm{~g}$ per day, equivalent to 29 $\mathrm{mg} / \mathrm{kg}$ body weight for a $70 \mathrm{~kg}$ adult. The highest EPA dosage consumed in this study (978 $\mathrm{mg} / \mathrm{kg}$ ) was nearly 34 times the EPA dosage that would be consumed by individuals as a dietary supplement (23).

From the limited publications on yeast oil supplementation, it appears it may have some health benefits. Further research is needed in order to better determine and understand the physiological effects of yeast oil on humans.

\section{OVERALL CONCLUSION}


In conclusion, n-3 LC-PUFAs have been shown to reduce weight gain, the risk of heart disease, TG, total cholesterol, LDL-C, and increase HDL-C. Many studies have shown that both EPA and DHA in the form of algae oil, yeast oil, or purified fish oil EPA and DHA ethyl esters have a hypotriglyceridemic effects. Algae oil has been shown to have differential effects on LDL-C, increase HDL-C, and decrease total cholesterol:HDL ratio and LDL:HDL ratio. However, algae may not be as effective as fish oil indicated by two studies in mice $(19,20)$. DHA-rich fish oil provided as ethyl esters may increase LDL-C and cholesterol, but may also increase HDL-C. Also, EPA-rich fish oil has been shown to lower cholesterol and decrease WAT. Yeast oil, a new dietary supplement on the market, is comprised mainly of EPA, has been found to be safe to use. Few studies have examined yeast oil supplementation, but a current study has shown to reduce total cholesterol and non-HDL cholesterol. However, the current research study is novel, has yet to be performed in previous literature, and will examine the effects of yeast oil plus algae oil supplementation compared to fish oil. 


\section{CHAPTER 2}

TITLE: THE EFFECT OF NON-MARINE VS. MARINE SOURCES OF THE OMEGA-3 FATTY ACIDS, DHA AND EPA, ON SERUM LIPOPROTEINS

AUTHORS $^{1}$ : MC Rodavich*, JS Ketz*, MJ Azain**, KM Barnes*²

$1 *$ Division of Animal and Nutritional Sciences, West Virginia University, Morgantown, WV 26506-6108. **Department of Animal and Dairy Science, University of Georgia, Athens, GA 30602.

${ }^{2}$ Address correspondence to Kimberly M. Barnes, Division of Animal and Nutritional Sciences, West Virginia University, PO Box 6108, Morgantown, WV 26506; Fax: (304) 293-2232; Phone: (304) 293-1841; E-mail: KMBarnes@mail.wvu.edu. 


\begin{abstract}
Fish oil (FO) is a marine source of the omega-3 fatty acids, eicosapentaenoic acid (EPA) and docosahexanaenoic acid (DHA), and has been shown to improve heart health. However, the effects of non-marine sources of omega-3 fatty acids are not well known. Male ICR mice (8 wk old, $\mathrm{n}=100$ ) were randomly assigned to dietary treatment groups: soy oil (SO; 0 g/kg DHA or EPA), FO (7.03 g/kg DHA + $12.64 \mathrm{~g} / \mathrm{kg}$ EPA), AO (7.03 g/kg DHA + $0.13 \mathrm{~g} / \mathrm{kg}$ EPA), YO (0.018 $\mathrm{g} / \mathrm{kg} \mathrm{DHA}+12.64 \mathrm{~g} / \mathrm{kg}$ EPA), or AO+YO (7.05 g/kg DHA + $12.77 \mathrm{~g} / \mathrm{kg}$ EPA) for 2 or 4 wks. Serum triglycerides (TG), total cholesterol (TC), and HDL-cholesterol (HDLC) were measured and non-HDL cholesterol (NHDLC) was calculated. Liver fatty acids were determined by gas chromatography. The liver mRNA expression was determined by real time RT-PCR. $\mathrm{P}<0.05$ is considered significant. The FO diet lowered all fractions of serum lipids and was the only diet to reduce TG. YO, alone and in combination with AO, reduced TC and NHDLC similar to FO at 4 wks. At both time points, FO-fed mice had significantly greater hepatic concentrations of EPA, DHA, and the omega-3 to omega- 6 ratio. There were no significant differences between any of the diet treatments at either time point in hepatic mRNA expression of apolipoprotein B100 (ApoB100), acyl-CoA:cholesterol acyltransferase (ACAT), diglyceride acyltransferase (DGAT), or low-density lipoprotein receptor (LDLR). At both time points FO-fed mice had significantly less 3-hydroxy-3-methyl-glutaryl-CoA reductase (HMGCR) expression compared to SO-fed mice. In conclusion, it appears that FO supplementation may be more beneficial in lowering serum lipoproteins than non-marine sources.
\end{abstract}




\section{INTRODUCTION}

There has been a vast amount of scientific and medical interest in the beneficial health effects of long chain omega-3 polyunsaturated fatty acids (n-3 LC-PUFAs), particularly eicosapentaenoic acid (EPA; 20:5n-3) and docosahexaenoic acid (DHA; 22:6n-6). Omega-3 LCPUFAs have been associated with reduced inflammation and a decreased risk of cardiovascular disease (CVD) incidence and mortality (1). Fish and fish oil (FO) consumption at 1-2 g/day have been shown to decrease the risk of CVD (1). The general recommendation is for 0.3-0.5 g from EPA and DHA and 0.8-1.1 g from $\alpha$-linolenic acid (ALA) (1). As a marine source, fish oil contains high concentrations of both EPA and DHA. However, the specific contributions of EPA and/or DHA on CVD risk are less well understood. An individual may also choose to exclude fish and fish products from their diet for various safety, sustainability, ethical, and personal reasons. Therefore, non-marine sources of n-3 LC-PUFAs, such as microalgae (or algae) and yeast, may be a valuable alternative (4).

Non-marine or non-fish derived algae oil (AO) is composed of high DHA concentrations, with very low EPA concentrations. In a meta-analysis of fifteen human studies, supplementation of 1-2 $\mathrm{g}$ of non-fish derived $\mathrm{AO}$ decreased serum triglycerides (TG) 15-20\% compared to baseline levels $\left(\mathrm{r}^{2}=0.25, \mathrm{p}<0.05\right)$. In another study, AO has also been shown to significantly increase high-density lipoprotein cholesterol (HDL-C) levels and to decrease low-density lipoprotein cholesterol (LDL-C) levels from baseline (18).

We have previously compared the effects of FO or AO on mice. FO significantly reduced serum TG, total cholesterol, and non-HDL-C (total cholesterol minus HDL-C) vs. soy oil ( $\mathrm{p}<$ 0.01), but AO only reduced serum total cholesterol at the higher dose (10 g DHA/kg diet vs. $5 \mathrm{~g}$ DHA/kg diet) (19). Subsequently, we determined that to equal the serum total cholesterol in the 
FO-fed mice, 3.5-5 times as much dietary DHA from AO needed to be fed (20). This may be due to the fact that less DHA is incorporated into liver and adipose tissue lipids in AO-fed mice compared to FO-fed mice $(19,20)$. Therefore, AO appears less effective than fish oil at reducing serum lipids in mice.

Non-marine derived yeast oil (YO) is comprised mainly of high EPA concentrations, with very little DHA concentrations. YO is new on the market and little research has been conducted on this particular PUFA source. YO is derived from the yeast strain, Yarrowia lipolytica, which was modified to produce high EPA levels (34-60\% EPA) (22). Published literature on the effects of YO showed that serum TC and non-HDL levels in rats were both significantly lower $(\mathrm{p}<0.05)$ at all times points in the medium $(488 \mathrm{mg} / \mathrm{kg} \mathrm{diet})$ and high $(976$ $\mathrm{mg} / \mathrm{kg}$ diet) EPA YO groups compared to control (olive oil) (23).

There is a vast amount of evidence supporting the health benefits of fish oil $(1,12,13,14)$, which is high in both EPA and DHA, on CVD risk factors. However, the specific contributions of EPA and DHA to these benefits are mostly unknown. Therefore, the objective of this study was to examine non-marine sources of EPA or DHA vs. fish oil on body weight and serum lipids.

\section{MATERIALS AND METHODS}

\section{A. Experimental Diets}

Diets were based on a modified AIN-93G diet with soy isolate as the protein source (Table 2). All diets consisted of $12 \%$ lipid by weight and the $\mathrm{AO}$ and $\mathrm{YO}$ containing diets were formulated to provide the level of DHA and/or EPA provided by the $12 \%$ FO diet $(7.03 \mathrm{~g}$ DHA/kg diet and $12.64 \mathrm{~g} \mathrm{EPA} / \mathrm{kg}$ diet). The fatty acid composition of the oils is presented in Table 3. All dietary ingredients, except algae and yeast oil, were purchased in purified form from 
Dyets, Inc. (Bethlehem, PA). The FO was produced from a menhaden fish source. The AO was DHASCO, produced from Crypthecodinium Cohnii, and was provided by Martek Biosciences Corporation (Columbia, MD). The YO was purchased from New Harvest (E. I. du Pont de Nemours and Company, Wilmington, DE) and was manufactured from a genetically modified strain of yeast, Yarowia lipolytica (22). Diets were flushed with nitrogen gas and stored at $-20^{\circ} \mathrm{C}$ prior to feeding.

\section{B. Animal Feeding Study}

All animal procedures were approved by the West Virginia University Animal Care and Use Committee. The animal feeding study was performed at the Office of Laboratory Animal Research at the Health Sciences Center on the West Virginia University campus located in Morgantown, WV. Male ICR mice ( $\mathrm{n}=100 ; 8$ wks old) were obtained from Harlan, Inc. (Madison, WI) and individually housed in cages with a $12 \mathrm{hr}$ light/dark cycle (lights on from $0700 \mathrm{hr}-1900 \mathrm{hr}$ ). After a 7 day acclimation period to the control powdered diet, mice were blocked by body weight and randomly assigned to one of five dietary treatment groups: SO, FO, $\mathrm{AO}, \mathrm{YO}$, or $\mathrm{AO}+\mathrm{YO}$.

Mice had free access to the diets and water at all times and fresh diet was provided three times per week to prevent oxidation and rancidity of the long chain fatty acids. Body weight was measured once per week and feed intake was measured three times per week. Ten mice per diet were euthanized by carbon dioxide asphyxia following 2 weeks of experimental diet consumption after a $5 \mathrm{hr}$ fast. Mice were bled by cardiac puncture and tissues including the liver, and epididymal and retroperitoneal fat pads were collected, weighed by the same researcher, and flash frozen within 10 minutes of euthanasia. Tissues were stored at $-80^{\circ} \mathrm{C}$ until analysis. The remaining ten mice per diet were euthanized and sampled following 4 weeks of experimental diet 
consumption after a $5 \mathrm{hr}$ fst. Body fat index was calculated as: (epididymal fat pad weight + retroperitoneal fat pad weight) / total body weight X 100 .

\section{Fatty Acid Analysis}

Total fatty acids were extracted from the liver for fatty acid analysis according to a modified method of Bligh and Dyers (24). Briefly, diced liver tissue $(\sim 0.5 \mathrm{~g})$ was added to $5 \mathrm{~mL}$ Tris/EDTA buffer. A $20 \mathrm{~mL}$ solution of chloroform:methanol:acetic acid (2:1:0.015, v/v/v) was added. Samples were centrifuged $\left(900 \mathrm{x} \mathrm{g}, 10^{\circ} \mathrm{C}, 10 \mathrm{~min}\right)$ and the bottom chloroform layer was collected. A solution of $10 \mathrm{~mL}$ chloroform:methanol (4:1, v/v) was added to the samples and centrifuged again $\left(900 \mathrm{x} \mathrm{g}, 10^{\circ} \mathrm{C}, 10 \mathrm{~min}\right)$ and the bottom chloroform layer was collected.

The fatty acids were methylated using the method by Park and Goins (25). The extracted lipids were dried under nitrogen gas in a $60^{\circ} \mathrm{C}$ water bath. A solution of $0.5 \mathrm{M} \mathrm{NaOH}$ in methanol was added, followed by the addition of $14 \%$ boron trifluoride. The samples were then incubated in a water bath at $90^{\circ} \mathrm{C}$ for $30 \mathrm{~min}$, then the fatty acid methyl esters were extracted in hexane. The samples were transferred to a glass vial and stored at $4^{\circ} \mathrm{C}$ until analyzed by gas chromatography at the University of Georgia (Athens, GA) as described previously (26). Heptadecanoic acid (17:1) was used as an internal standard and fatty acids were identified using retention times and peak area based on mixed fatty acid methyl ester standards (GLC-502, GLC484, GLC-87, GLC-455; Nu-Check Prep, Inc., Elysian, MN).

\section{Serum Lipid and Lipoprotein Measurements}

Blood was allowed to clot, then centrifuged for 20 minutes at $4^{\circ} \mathrm{C}$ at $2000 \mathrm{x}$ g. Serum was collected and frozen at $-20^{\circ} \mathrm{C}$ until analysis for triglycerides, total cholesterol, and HDL cholesterol using commercially available colorimetric kits (Wako Chemicals USA, Inc.) 
following the manufacturer's protocol. To calculate non-HDL cholesterol, HDL cholesterol was subtracted from total cholesterol.

\section{E. RNA Isolation and Gene Expression}

The relative liver mRNA expression of several genes involved in lipid metabolism (HMG-CoA Reductase, LDL-Receptor, diglyceride acyltransferase (DGAT), ApoB100, acylCoA:cholesterol acyltransferase (ACAT)) were determined by real time RT-PCR as previous described by Barnes et al. with slight modifications (27). Total RNA was extracted (50-75 grams liver tissue) with TRIzol Reagent (Invitrogen, Carlsbad, CA) following the manufacturer's protocol. The RNA pellet was dissolved in nuclease-free, sterile water and quantified using a NanoDrop 1000 spectrophotometer (Thermo Scientific, Waltham, MA). Total RNA $(1 \mu \mathrm{g})$ was heat denatured $\left(80^{\circ} \mathrm{C}\right.$ for $3 \mathrm{~min}$, then chilled on ice) and reverse transcribed using the iScript cDNA Synthesis Kit (Bio-Rad Laboratories, Hercules, CA) following the manufacturer's protocol. Gene-specific primers were designed to span a splice-junction and amplify $~ 100 \mathrm{bp}$ segments (Table 4).

The final real-time reactions were run in triplicate in a reaction volume of $25 \mu \mathrm{L}$, which contained $10 \mathrm{ng}$ of reverse-transcribed RNA, $0.2 \mu \mathrm{g}$ gene-specific primers, and 1 X SYBR Green Supermix (Bio-Rad Laboratories). Reactions were performed in a C1000 iCycler Thermal Cycler

(Bio-Rad Laboratories) with an initial stage of $95^{\circ} \mathrm{C}$ for $3 \mathrm{~min}$, followed by 40 cycles of $95^{\circ} \mathrm{C}$ for $15 \mathrm{sec}$ and $60^{\circ} \mathrm{C}$ for $1 \mathrm{~min}$. A melt curve was run to confirm the production of a single product. Efficiency of amplification was determined using DART (28) and relative expression was calculated using the $\Delta \Delta \mathrm{C}_{\mathrm{T}}$ method accounting for gene-specific efficiencies (29) using acidic ribosomal phosphoprotein (ARP) as the housekeeping gene.

\section{F. Statistical Analysis}


An individual mouse was the experimental unit for all analyses $(n=100)$. Data was analyzed by analysis of variance (ANOVA) using a fixed model testing the main effects of diet and block within time period. Block $\mathrm{x}$ diet interactions were tested and all were found not to be significant, therefore they were removed from the model. F-tests, least squares means, and standard error of the mean (SEM) were calculated using the PROC MIXED procedure of SAS (SAS Inst. Inc., Cary, NC). Means were separated by least significant difference test with $\mathrm{P}<$ 0.05 considered significant and with $\mathrm{P}<0.10$ considered as a trend.

\section{RESULTS}

\section{A. Feed Intake, Body Weight, and Tissue Weight}

There were no significant differences among any of the diet treatments at any time points of total average daily feed intake (TADFI), final body weight (FBW), retroperitoneal (RP) adipose tissue weight, or epididymal (EPI) adipose tissue weight (Table 5). Consequently, there were no significant differences in BFI between any of the diet treatments. However, there was a trend at 2 weeks for $\mathrm{AO}+\mathrm{YO}-$ fed mice to have a greater BFI compared to all other dietary treatments. There was a trend at 2 weeks for SO-fed mice to have greater TADFI compared to all other dietary treatments. There was a trend at 2 weeks for RP weight to be greater in the AO and AO+YO-fed mice compared to all other dietary treatments (Table 5). At 2 weeks, FO and YOfed mice had significantly greater relative liver weights compared to SO-fed mice. At 4 weeks, FO-fed mice had significantly greater relative liver weights compared to SO-fed mice $(\mathrm{p}<0.05)$ (Fig. 3).

\section{B. Serum Lipids and Lipoproteins}


At 2 weeks, all dietary treatments, except YO-fed mice, had significantly lower serum total cholesterol compared to SO-fed mice. At 4 weeks, all dietary treatments, except AO-fed mice, had significantly lower serum total cholesterol compared to SO-fed mice ( $\mathrm{p}<0.05)$ (Fig. 4A). This reduction was due primarily to reductions in non-HDL cholesterol ( $\mathrm{p}<0.05)$ (Fig. 4B). None of the diet treatments had significantly different HDL cholesterol levels compared to SOfed mice (Fig. 4C). However, at 2 weeks the AO-fed mice had significantly greater HDL cholesterol levels compared to the FO and YO-fed mice, and at 4 weeks the AO-fed mice had significantly greater $\mathrm{HDL}$ cholesterol levels compared to the $\mathrm{FO}, \mathrm{YO}$, and $\mathrm{AO}+\mathrm{YO}-$ fed mice ( $\mathrm{p}$ $<0.05)$. The FO-fed mice had significantly lower serum TGs compared to the SO-fed mice at 2 weeks ( $\mathrm{p}<0.05$ ), but not at 4 weeks (Fig. 4D). However, FO-fed mice had significantly lower serum TGs at 4 weeks compared to YO-fed mice $(\mathrm{p}<0.05)$.

\section{Fatty Acid Analysis of the Liver}

There were no significant differences among any of the dietary treatments in hepatic incorporation of stearic acid (C18:0), arachidic acid (C20:0), eicosenoic acid (C20:1), and eicosadienoic acid (C20:2) (Table 6). At 2 and 4 weeks, FO-fed mice had significantly greater hepatic EPA (C20:5) and DHA (C22:6) concentrations than all other diet treatments $(\mathrm{p}<0.05)$ (Table 6). At 2 weeks, all diet treatments had significantly greater EPA concentrations than SOfed mice in the order of $\mathrm{FO}>\mathrm{AO}+\mathrm{YO}>\mathrm{YO}>\mathrm{AO}>\mathrm{SO}$. At 4 weeks, AO-fed mice did not differ in EPA compared to SO-fed mice. $\mathrm{YO}$ and $\mathrm{AO}+\mathrm{YO}-$ fed mice were similar in EPA, but still less than FO-fed mice. At 2 and 4 weeks, all diet treatments had significantly greater DHA concentrations than SO-fed mice. At 2 weeks, $\mathrm{AO}$ and $\mathrm{AO}+\mathrm{YO}-$ fed mice were similar, greater than YO-fed mice, but less than FO-fed mice. At 4 weeks, DHA was in the order of FO > $\mathrm{AO}+\mathrm{YO}>\mathrm{AO}>\mathrm{YO}>\mathrm{SO}$. 
At 2 and 4 weeks, FO and YO-fed mice had significantly greater docosapentaenoic acid (C22:5) content compared to SO, AO, and AO+YO-fed mice. At weeks 2 and 4, SO-fed mice had significantly greater arachidonic acid (ARA; C20:4), an omega-6 LC-PUFA, concentrations than all other diet treatments. At weeks 2 and 4, FO-fed mice had significantly less linoleic acid (C18:2), an omega-6 LC-PUFA, than all other diet treatments. At week 2, FO and AO+YO-fed mice had significantly less $\alpha$-linolenic acid (C18:3n-3), an omega-3 LC-PUFA, concentrations than any other diet treatments. However, at week 4 there were no significant differences between any of the diet treatments in $\alpha$-linolenic acid concentration.

At week 2, SO-fed mice had significantly less SFA concentrations then all other diet treatments. At week 4, FO-fed mice had significantly greater SFA concentrations than all other diet treatments due to greater myristic acid (C14:0) and palmitic acid (C16:0). There were no significant differences in PUFA concentration between any of the diet treatments at any time points. At 2 weeks, SO-fed mice had significantly greater MUFA concentrations compared to FO and $\mathrm{AO}+\mathrm{YO}-\mathrm{fed}$ mice. At 4 weeks, SO-fed mice had significantly greater MUFA concentrations compared to FO, YO, and $\mathrm{AO}+\mathrm{YO}-$ fed mice due to greater oleic acid (C18:1) content. FO-fed mice had significantly greater palmitoleic acid (C16:1) content compared to all dietary treatments at both 2 and 4 weeks.

At weeks 2 and 4, the FO-fed mice had significantly greater total omega-3 (n-3) concentrations than any other diet treatments due to the greater EPA and DHA levels. At week 2, SO-fed mice had significant greater omega-6 (n-6) concentrations than all other diet treatments. At week 4, the SO and YO-fed mice had significantly greater n-6 concentrations than all other diet treatments due to greater ARA, gamma-linolenic acid (GLA; C18:3n-6), and dihomogamma-linolenic acid (DGLA; C20:3n-6) concentrations. At both 2 and 4 weeks, FO-fed mice 
had significantly less n-6 concentrations compared to all other diet treatments. At weeks 2 and 4 , FO-fed mice had significantly greater omega-3 to omega-6 ratios (n-3:n-6) compared to all other diet treatments due to high n-3 levels along with low n-6 levels.

\section{D. mRNA Relative Expression of Selected Genes in the Liver}

There were no significant differences between any of the diet treatments at any time points in hepatic relative mRNA expression of the following genes: acyl-CoA:cholesterol acyltransferase (ACAT), apolipoprotein B (ApoB100), diglyceride acyltransferase (DGAT), and low-density lipoprotein receptor (LDLR) (Fig. 5A-D, respectively). However, at weeks 2 and 4, the FO-fed mice had significantly less 3-hydroxy-3-methyl-glutaryl-CoA reductase (HMGCR) expression compared to the SO-fed mice ( $\mathrm{p}<0.05)$ (Fig. 5E). AO and AO+YO-fed mice had less $(\mathrm{p}<0.05)$ HMGCR expression compared to YO-fed mice, although it was not different from SO.

\section{DISCUSSION}

It has previously been reported that the n-3 LC-PUFAs, EPA and DHA, have been associated with a decreased risk of CVD incidence (1). Mice in this study fed n-3 LC-PUFAs did not reduce body weight, body fat index, or adipose tissue in the RP and EPI fat pad depots (Table 5). Our results are contrary to other findings, but these differences could be due to differences in study length ( 1 week to 7 weeks) or in dietary fat content (10.4\% to $40 \%$ energy from fat) $(12,13,14)$. However, our results are similar to a study by Tou et al., in which SpragueDawley rats fed fish oil from a Menhaden source (12\% diet from lipid) had no significant differences between any diet groups (corn, flaxseed, krill, salmon, or tuna oils) in RP adipose tissue weight. Rats fed a menhaden-diet had similar liver weights ( $\mathrm{g} / 100 \mathrm{~g}$ body weight) compared to corn oil-fed rats (30). This is contradictory to the results in our study where FO-fed 
mice had significantly greater relative liver weights compared to all other dietary treatments (Table 5). Increased liver weight can be associated with many negative health consequences such as hepatic steatosis, non-alcoholic liver disease, cirrhosis, and liver cancer (31). A possible cause of increased hepatic weight can be excess lipid storage in the liver. However, in our study this was not the case because there were no significant differences in hepatic total lipid content at 2 weeks and SO-fed mice had significantly greater hepatic total lipid content at 4 weeks compared to all other diet treatments (Bush M and Barnes KM, unpublished results). There were also no significant differences in TG content of the liver between any of the diet treatments at any time point (Bush M and Barnes KM, unpublished results). Therefore, the increased liver weights in the FO-fed mice cannot be attributed to hepatic total lipid or TG content. Possible explanations for the differences in liver weight could be due to hepatic protein, fluid, or glycogen content. It has previously been reported that fish oil supplementation decreases serum TG concentration $(12,13,14)$. In support of this, mice in our study fed fish oil lowered all fractions of plasma lipids, and only FO reduced serum TGs (Fig. 4). There are three possible mechanisms in which omega-3 PUFAs may lower serum TGs: 1) reduced substrate (i.e. fatty acids) availability, which could be secondary to an increase in $\beta$-oxidation, decreased free fatty acid delivery to the liver or decreased hepatic fatty acids synthesis, 2) increased phospholipid synthesis, or 3) decreased activity of triglyceride-synthesizing enzymes (DGAT) (32). In our study, the first mechanism is unlikely since there was similar TG and lipid content in the liver among the different dietary treatments. In terms of the second mechanism, we did not measure phospholipid synthesis. As for the final mechanism, we found no change in DGAT mRNA expression, however we did not measure the activity of this enzyme. 
$\mathrm{YO}$, alone and in combination with $\mathrm{AO}$, reduced total and non-HDL cholesterol similar to FO at 4 wks. At 2 weeks, AO also reduced total and non-HDL cholesterol. Reductions in total cholesterol were primarily due to reductions in non-HDL cholesterol (Fig. 4). Therefore, it appears that the reductions in serum total and non-HDL cholesterol may be attributed to the EPA content of the diet. In support of these findings, a previous study by MacKenzie et al. found that rats fed yeast oil in medium and high-EPA groups (98 mg EPA/kg and $488 \mathrm{mg}$ EPA/kg body weight per day, respectively) had significantly lower total and non-HDL cholesterol compared to a control diet (olive oil) (23). In our study, AO-fed mice had similar serum HDL levels as SO-fed mice, but these levels were numerically greater than all other dietary treatments at both 2 and 4 weeks. Therefore, it appears that the increases in serum HDL-cholesterol may be due to the DHA content of the diet. In a previous study by our lab, mice fed algae oil resulted in a significant decrease in total cholesterol compared to SO-fed mice after 2 weeks of supplementation, but higher doses of algae oil were needed in order to significantly reduce total cholesterol at 4 weeks (20).

It has previously been reported that HMG-CoA reductase mRNA expression is downregulated with n-3 LC-PUFAs supplementation in both in vivo (33) and in vitro studies $(34,35)$. Similarly in our study, FO-fed mice significantly down-regulated HMG-CoA reductase expression compared to SO-fed mice at both time points (Fig 5E). In a rat cell culture study by Kaur et al., DHA was more effective at down-regulating HMG-CoA reductase expression than EPA ( $76 \%$ vs. $53 \%$, respectively) compared with oleic acid $(\mathrm{P}<0.05)(33)$. This is similar to the results found in our study evidenced by the AO-fed mice having significantly lower HMG-CoA reductase expression compared with YO-fed mice $(\mathrm{P}<0.05)$ (Fig 5E). These results are important because HMG-CoA reductase is an important point for the regulation of cholesterol 
synthesis. HMG-CoA reductase is the rate limiting enzyme in cholesterol synthesis, reducing 3hydroxy-3-methylgluaryl CoA (HMG-CoA) to mevalonate (6). Therefore, suppressed HMGCoA reductase levels in FO-fed mice could be a possible explanation for significantly decreased total cholesterol levels compared to SO-fed mice. However, this explanation may not hold true for AO and YO-fed mice. Even though YO-fed mice had numerically greater hepatic HMGCR mRNA expression compared to all dietary treatments at both 2 and 4 weeks, YO-fed mice had numerically decreased serum TC levels at 2 weeks and significantly lower TC at 4 weeks compared to SO-fed mice. Similarly, AO-fed mice had numerically lower hepatic HMGCR mRNA expression compared to SO and YO-fed mice at 4 weeks, but AO-fed mice had similar serum TC levels compared to SO-fed mice.

FO-fed mice had numerically lower ACAT mRNA levels than SO-fed mice (Fig. 5A). These results are supported by previous work in rats where fish oil-fed rats had significantly lower hepatic ACAT mRNA expression compared to rats fed corn oil $(36,37)$. We detected no significant differences in LDL-receptor mRNA expression between any of the diet treatments (Fig. 5D). LDL is the primary carrier of cholesterol in the blood, from which $60 \%$ is taken up by LDL receptors in the liver, adrenals, and various other tissues. The number and activity of LDL receptors is a determinant of the level of LDL-C in the blood (6). Interestingly however, FO, $\mathrm{YO}$, and AO+YO-fed mice had significantly lower serum non-HDL levels compared to the SOfed mice (Fig. 4B). There were also no significant differences in DGAT (Figure 5C) or ApoB100 (Fig. 5B) mRNA expression between any of the diet treatments. These findings are consistent with two previous studies in rats fed a fish oil diet compared to rats fed control diets (corn oil and sunflower oil, respectively) $(37,38)$. Our data indicates that the changes in serum lipids in omega-3 fatty acid-fed rodents may not be the result of altered transcription. 
Because the liver is the major site of n-3 LC-PUFA synthesis and metabolism, it is important to analyze the PUFA deposition in the liver from different dietary sources. Increasing tissue omega-3 LC-PUFAs can employ beneficial health effects by influencing 1) eicosanoid pathways, which alters inflammation, 2) modulation of molecules and enzymes involved with various signaling pathways and cell functions, 3) cell membrane phospholipids and fluidity, and 4) direct effects on gene expression (39). In our study, mice fed AO, alone and in combination with YO, had significantly lower ARA (C20:4) deposition in the liver compared to SO, FO, and YO-fed mice. Similar to a previous study (30), FO-fed mice had significantly lower ARA deposition in the liver compared to SO-fed mice (Table 6). These findings may have important clinical implications because decreased ARA reduces the synthesis of pro-inflammatory series-2 eicosanoids (41).

At both time points, FO-fed mice had significantly greater hepatic EPA (C20:5) and DHA (C22:6) concentrations than all other diet treatments (Table 6). This is consistent with our findings in which FO-fed mice had significantly greater EPA and DHA incorporation into skeletal muscle and EPI adipose tissue compared to all other diet treatments at 4 weeks. FO-fed mice also had significantly less DHA excretion in the feces compared to AO and AO+YO-fed mice at 2 and 4 weeks. However, there were no significant differences between $\mathrm{FO}, \mathrm{AO}+\mathrm{YO}$, and YO-fed mice in the excretion of EPA in the feces (Ketz JS and Barnes KM, unpublished results). These results are further supported by a previous study at West Virginia University where greater doses of algae oil were required in order to obtain equal liver and adipose tissue DHA concentrations as mice fed fish oil (20). This could account for the lesser response to algae and yeast oils. AO-fed mice may have had greater hepatic EPA incorporation at 2 weeks compared to SO-fed mice due to the liver's ability to retro-convert DHA to EPA. YO-fed mice 
may have had significantly greater hepatic DHA incorporation at 2 and 4 weeks compared to SO-fed mice due to the liver's ability to convert EPA to DHA.

At week 2, SO-fed mice had significantly less hepatic SFA concentrations than all other diet treatments. At week 4, FO-fed mice had significantly greater hepatic SFA concentrations than all other diet treatments due to greater hepatic myristic acid (C14:0) and palmitic acid (C16:0) levels. These differences are consistant with the differences in the fatty acid profile of the oils themselves. There were no significant differences in hepatic PUFA concentration between any of the diet treatments at any time points. At 2 weeks, SO-fed mice had significantly greater hepatic MUFA concentrations compared to FO and AO+YO-fed mice. At 4 weeks, SOfed mice had significantly greater hepatic MUFA concentrations compared to FO, YO, and AO+YO-fed mice due to greater oleic acid (C18:1) content. SO-fed mice may have had the greatest concentrations of liver MUFA because the soy oil and algae oil had greater amounts of oleic acid (20\% and 25\%, respectively) compared to the fish oil and yeast oil (8\% and 5\%, respectively) (Table 3). Moderate dietary MUFA consumption has been found to be cardioprotective in promoting optimal blood lipids, improving blood pressure and insulin sensitivity, and regulating blood glucose levels (40).

In our study, FO-fed mice had significantly greater hepatic omega-3 PUFA concentrations at both time points compared to all other diet treatments (Table 6). FO-fed mice also had significantly less hepatic omega-6 PUFA concentrations at both time points compared to all other diet treatments (Table 6). These results are consistent with findings from previous studies $(20,35)$. Therefore, at both time points FO-fed mice had significantly greater hepatic omega- 3 to omega- 6 ratios compared to all other diet treatments (Table 6). The ratio of omega- 6 to omega-3 essential fatty acids has important implications because linoleic acid (omega-6) and 
alpha-linolenic acid (omega-3) compete for the same rate limiting enzyme in the synthesis of LC-PUFAs, $\Delta 6$-desaturase. A high omega-6 to omega-3 ratio and a low omega-3 to omega-6 ratio, which is typical in Western diets, promote the progression of many diseases such as CVD, cancer, inflammatory diseases, and autoimmune diseases. There are many discrepancies in the literature as to the optimal omega-6 to omega-3 ratio in humans, ranging from 1:1 to 4:1, depending on the individual and the disease condition (41). The omega-6 to omega-3 ratios in our diets were as follows: $\mathrm{SO} ; 7.03>\mathrm{AO} ; 3.61>\mathrm{YO} ; 2.95>\mathrm{AO}+\mathrm{YO} ; 1.80>\mathrm{FO} ; 0.40$.

\section{SUMMARY AND CONCLUSION}

The present study evaluated alternative sources of omega-3 LC-PUFAs on serum lipids and lipoproteins, hepatic fatty acid composition, and hepatic gene expression. Our study is novel because we evaluated the effects of non-marine sources versus marine sources of omega-3 LCPUFAs. There are few studies that assess the effects of YO on health and cardiovascular parameters.

Our study showed that FO supplementation may be more beneficial at lowering serum lipids compared to non-marine sources. It appears that EPA is more beneficial at lowering cholesterol since YO-fed mice, but not AO-fed mice, lowered serum cholesterol and NHDLC. FO was also the only diet to significantly lower serum TGs. Mice fed a diet consisting of FO were also more efficient at incorporating EPA and DHA into the liver as well as down-regulating hepatic HMGCR mRNA expression. However, FO also had the highest omega-3 to omega-6 ratio.

These results are significant because HMGCR is the rate limiting enzyme in cholesterol synthesis. The ratio of omega- 6 to omega-3 essential fatty acids has important implications because linoleic acid (omega-6) and alpha-linolenic acid (omega-3) compete for the same rate 
limiting enzyme in the synthesis of LC-PUFAs, $\Delta 6$-desaturase. However, a high omega-6 to omega-3 ratio, which is typical in Western diets, promotes the progression of many diseases such as CVD, cancer, inflammatory diseases, and autoimmune diseases.

Future research into the dietary consumption of marine vs. non-marine sources of omega3 LC-PUFAs in the prevention of CVD is a promising area of contribution. Further research would benefit from comparing different sources of marine origin vs. non-marine origin and studying a variety of hepatic genes involved in lipid metabolism. 
Figure 1: Chemical structures of docosahexaenoic acid (DHA), eicosapentaenoic acid (EPA), and arachidonic acid (ARA). Molecules are oriented with methyl (omega) terminal on the reader's left (39).

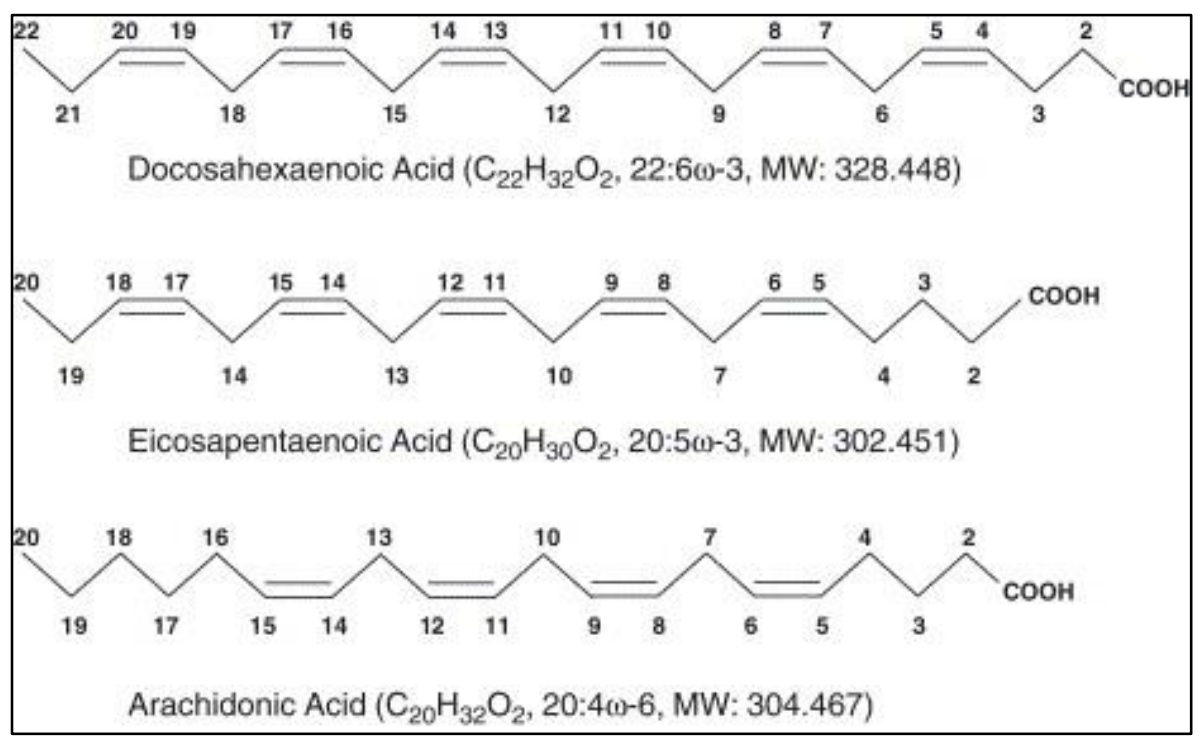


Figure 2: Cholesterol Synthesis Pathway (7)

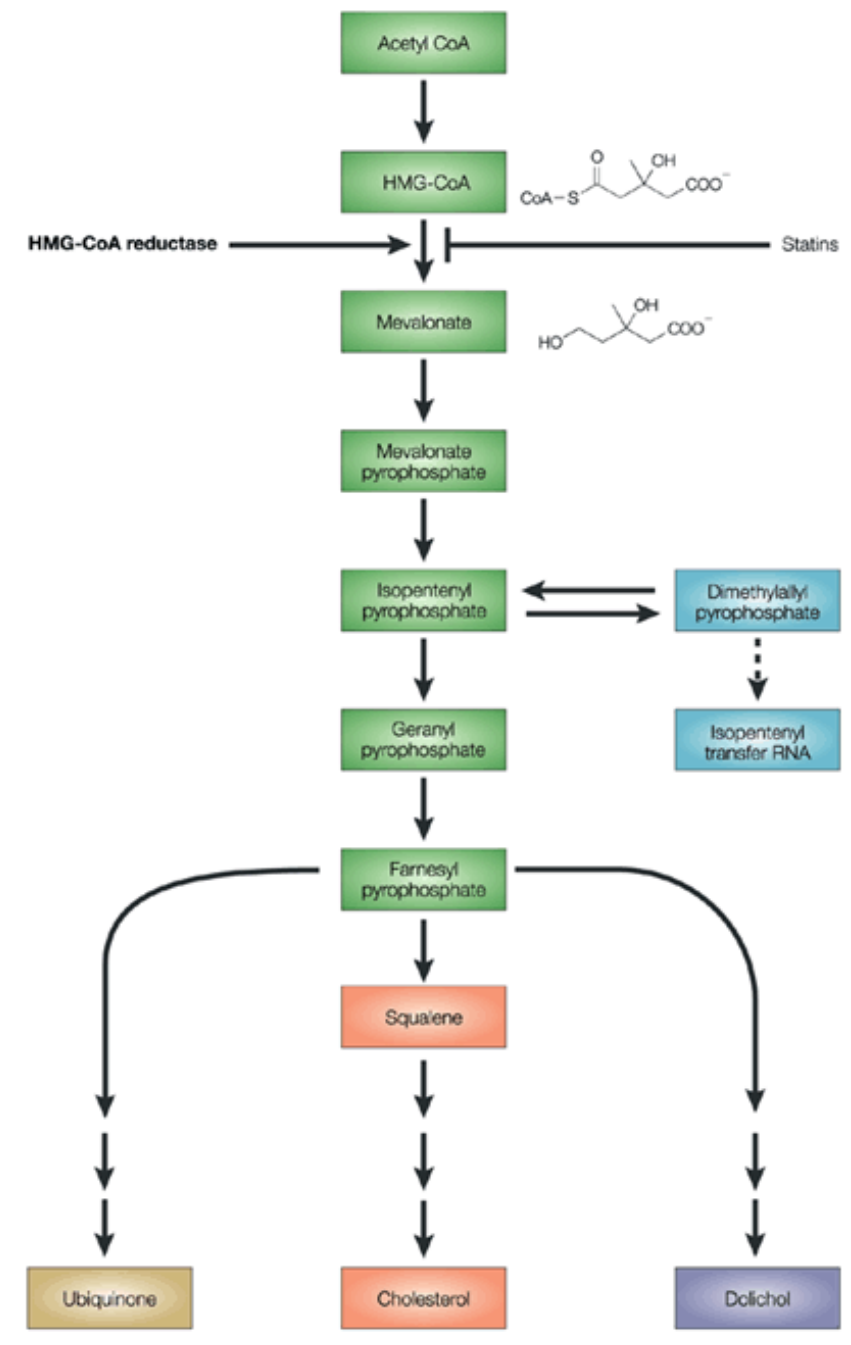

Nature Reviews | Drug Discovery 
Table 1. Types of Marine vs. Non-Marine Sources of Omega-3 Fatty Acids (1)

\begin{tabular}{|cc|}
\hline Marine Sources & Non-Marine Sources \\
\hline Tuna & Flaxseed* \\
Sardines & Walnuts* \\
Salmon & Soybean Oil** \\
Mackerel & Canola Oil* \\
Menhaden ** & Hempseed* \\
Herring & Butternuts* \\
Rainbow Trout & Algae Oil ** \\
Halibut & Yeast Oil ** \\
Cod & \\
Haddock & \\
Catfish & \\
Flounder/Sole & \\
Oyster & \\
Lobster & \\
Alaskan King Crab & \\
Shrimp & \\
Scallop & \\
\hline
\end{tabular}

* Plant sources, typically high in ALA

** Sources used in our study 
Table 2. Ingredient Composition of the Experimental Diets Fed to Mice

\begin{tabular}{|c|c|c|c|c|c|}
\hline Ingredient $(\mathbf{g} / \mathbf{k g})^{1}$ & SO & FO & AO & YO & $\mathrm{AO}+\mathbf{Y O}$ \\
\hline Isolated Soy Protein & 200 & 200 & 200 & 200 & 200 \\
\hline Cornstarch & 345.42 & 345.42 & 345.42 & 345.42 & 345.42 \\
\hline Dextronized Cornstarch & 132 & 132 & 132 & 132 & 132 \\
\hline Sucrose & 100 & 100 & 100 & 100 & 100 \\
\hline Cellulose & 50 & 50 & 50 & 50 & 50 \\
\hline Soy Oil & 120 & - & 92.7 & 97.79 & 70.49 \\
\hline Fish Oil $^{2}$ & - & 120 & - & - & - \\
\hline Algae Oil $^{3}$ & - & - & 27.3 & - & 27.3 \\
\hline Yeast Oil $^{4}$ & - & - & - & 22.21 & 22.21 \\
\hline AIN-93G Mineral Mix & 35 & 35 & 35 & 35 & 35 \\
\hline AIN-93G Vitamin Mix & 10 & 10 & 10 & 10 & 10 \\
\hline L-Cysteine & 2.54 & 2.54 & 2.54 & 2.54 & 2.54 \\
\hline L-Methionine & 2.54 & 2.54 & 2.54 & 2.54 & 2.54 \\
\hline Choline Bitartrate & 2.5 & 2.5 & 2.5 & 2.5 & 2.5 \\
\hline
\end{tabular}

${ }^{1}$ All ingredients except algae and yeast oils were obtained from Dyets, Inc. (Bethlehem, PA).

Algae oil was produced by Martek Biosciences Corporation (Columbia, MD). Yeast oil was

produced by New Harvest (E. I. du Pont de Nemours and Company, Wilmington, DE).

${ }^{2}$ Fish oil contained $10.54 \%$ EPA $+5.86 \%$ DHA

${ }^{3}$ Algae oil contained $0.47 \% \mathrm{EPA}+25.76 \% \mathrm{DHA}$

${ }^{4}$ Yeast oil contained $56.94 \% \mathrm{EPA}+0.08 \%$ DHA 
Table 3. Dietary Fatty Acid Composition of the Oils.

\begin{tabular}{ccccc}
\hline \hline $\begin{array}{c}\text { Fatty Acids } \\
(\mathbf{m g} \text { FA/g oil })\end{array}$ & \multicolumn{2}{c}{ Treatment Oils } & \\
& SO & FO & AO & YO \\
\hline C14:0 & 0.06 & 15.15 & 19.38 & 0.13 \\
C16:0 & 10.00 & 25.76 & 12.92 & 3.63 \\
C16:1 & 0.08 & 16.69 & 3.51 & 0.55 \\
C18:0 & 3.30 & 3.34 & 0.80 & 2.39 \\
C18:1 & 19.75 & 8.39 & 25.12 & 5.19 \\
C18:2 & 57.06 & 1.66 & 1.59 & 19.98 \\
C18:3 & 8.16 & 1.85 & 0.04 & 1.35 \\
C20:5 & 0.01 & 10.54 & 0.47 & 56.81 \\
C22:6 & ND & 5.86 & 25.79 & 0.08 \\
Other & 1.59 & 10.76 & 10.37 & 9.89 \\
\hline \hline
\end{tabular}

${ }^{1}$ Fatty acids from the oils were analyzed by gas chromatography and expressed as a percent of total fatty acids (mg FA/g oil).

${ }^{2} \mathrm{SO}=$ soy oil $; \mathrm{FO}=$ fish oil $; \mathrm{AO}=$ algae oil $; \mathrm{YO}=$ yeast oil

${ }^{3} \mathrm{ND}=$ none detected 
Table 4. Details of Primers Used for Real-time Reverse-Transcription PCR

\begin{tabular}{ccccc}
\hline Gene $^{1}$ & $\begin{array}{c}\text { GenBank } \\
\text { Accession No. }\end{array}$ & Forward Primer & Reverse Primer & $\begin{array}{c}\text { Product } \\
\text { Size (bp) }\end{array}$ \\
\hline \hline HMGCR & NM_008255 & GGGTCTGGACGAAGATGTGT & TGCTCAATGTCCATGCTGAT & 93 \\
LDLR & NM_010700 & AACCTGGAAGGCAGCTACAA & CGGTTGGTGAAGAGCAGATAG & 122 \\
DGAT & NM_010046 & GAATATCCCCGTGCACAAGT & GGAAGAAGGCTGAGGTCAAA & 118 \\
ApoB100 & NM_009693 & TCAACCTTGCAGTTTCTGGA & CACAGTGTTGAAGTGTTCCTTTG & 105 \\
ACAT-1 & NM_144784 & CCCATCACCATCTCAGTGAA & GGTCTTGAGCTTTGGCACTT & 124 \\
ARP & NM_007475 & GCGACCTGGAAGTCCAACTA & GCTCCCACAATGAAGCATTT & 77 \\
\hline
\end{tabular}

${ }^{1}$ HMGCR = 3-hydroxy-3-methyl-glutaryl-CoA reductase, LDLR = low-density lipoprotein receptor,

DGAT $=$ diglyceride acyltransferase, $\mathrm{ApoB} 100=$ apolipoproteinB 100, ACAT $=$ acetyl-Coenzyme A acetyltransferase-1, ARP = acidic ribosomal phosphoprotein, housekeeping gene 
Figure 3. Relative Liver Weights (g/gbw). Data are presented as mean \pm SEM. Different letters within week indicate significant differences between treatments $(p<0.05)$.

SO $\square$ FO $\square$ AO $\square$ YO $\mathbb{N A O + Y O}$

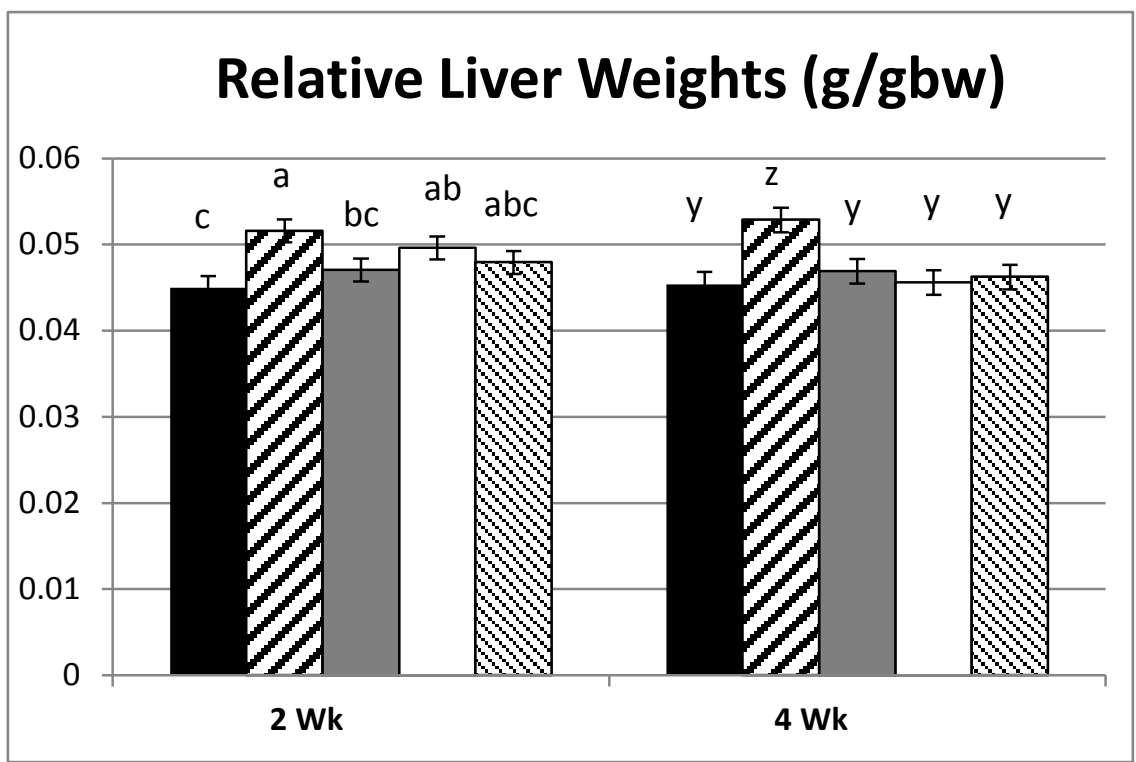


Table 5. Effect of Dietary Treatment on Feed Intake, Body Weight, and Tissue Weight

\begin{tabular}{|c|c|c|c|c|c|c|c|c|}
\hline \multirow[b]{2}{*}{ Measurement $^{2}$} & \multicolumn{6}{|c|}{ Diet $^{1}$} & \multirow[b]{2}{*}{ SEM } & \multirow[b]{2}{*}{ P-Value } \\
\hline & Week & SO & FO & AO & YO & $\mathrm{AO}+\mathrm{YO}$ & & \\
\hline \multirow{2}{*}{ FBW (g) } & 2 & 37.21 & 37.62 & 37.73 & 35.79 & 37.98 & 0.608 & 0.109 \\
\hline & 4 & 39.86 & 40.08 & 39.68 & 40.15 & 40.92 & 1.019 & 0.928 \\
\hline \multirow{2}{*}{ BFI (\%) } & 2 & 2.94 & 2.54 & 2.94 & 2.52 & 3.18 & 0.198 & 0.098 \\
\hline & 4 & 4.68 & 3.39 & 3.93 & 3.63 & 4.07 & 0.445 & 0.316 \\
\hline \multirow{2}{*}{ TADFI (g) } & 2 & 6.25 & 6.05 & 5.17 & 5.80 & 5.43 & 0.282 & 0.065 \\
\hline & 4 & 5.75 & 5.67 & 5.91 & 5.76 & 5.10 & 0.296 & 0.362 \\
\hline \multirow{2}{*}{ RP Weight (g) } & 2 & 0.25 & 0.21 & 0.29 & 0.22 & 0.29 & 0.0248 & 0.098 \\
\hline & 4 & 0.66 & 0.28 & 0.38 & 0.35 & 0.41 & 0.122 & 0.271 \\
\hline \multirow{2}{*}{$\begin{array}{l}\text { EPI Weight } \\
\text { (g) }\end{array}$} & 2 & 0.85 & 0.74 & 0.83 & 0.69 & 0.93 & 0.065 & 0.119 \\
\hline & 4 & 1.23 & 1.09 & 1.19 & 1.12 & 1.28 & 0.131 & 0.845 \\
\hline
\end{tabular}

${ }^{1} \mathrm{SO}=$ soy oil diet; $\mathrm{FO}=$ fish oil diet; $\mathrm{AO}=$ algae oil diet; $\mathrm{YO}=$ yeast oil diet; $\mathrm{AO}+\mathrm{YO}=$ algae oil plus yeast oil diet; SEM $=$ standard error of the mean .

${ }^{2} \mathrm{FBW}=$ final body weight; $\mathrm{BFI}(\%)=$ body fat index $(\%) ; \mathrm{TADFI}=$ total average daily feed intake; RP Weight $=$ retroperitoneal tissue weight; EPI Weight $=$ epididymal tissue weight. 
Figure 4. Effect of Dietary Treatment on Serum Lipids.

A. Total Cholesterol, B. HDL Cholesterol, C. Triglycerides, D. Non-HDL Cholesterol. Data are presented as means \pm SEM. Different letters within week indicate significant differences between treatments $(\mathrm{p}<0.05)$.

$\square$ SO $\square$ FO $\square$ AO $\square$ YO $\mathbb{A}$ AO+YO
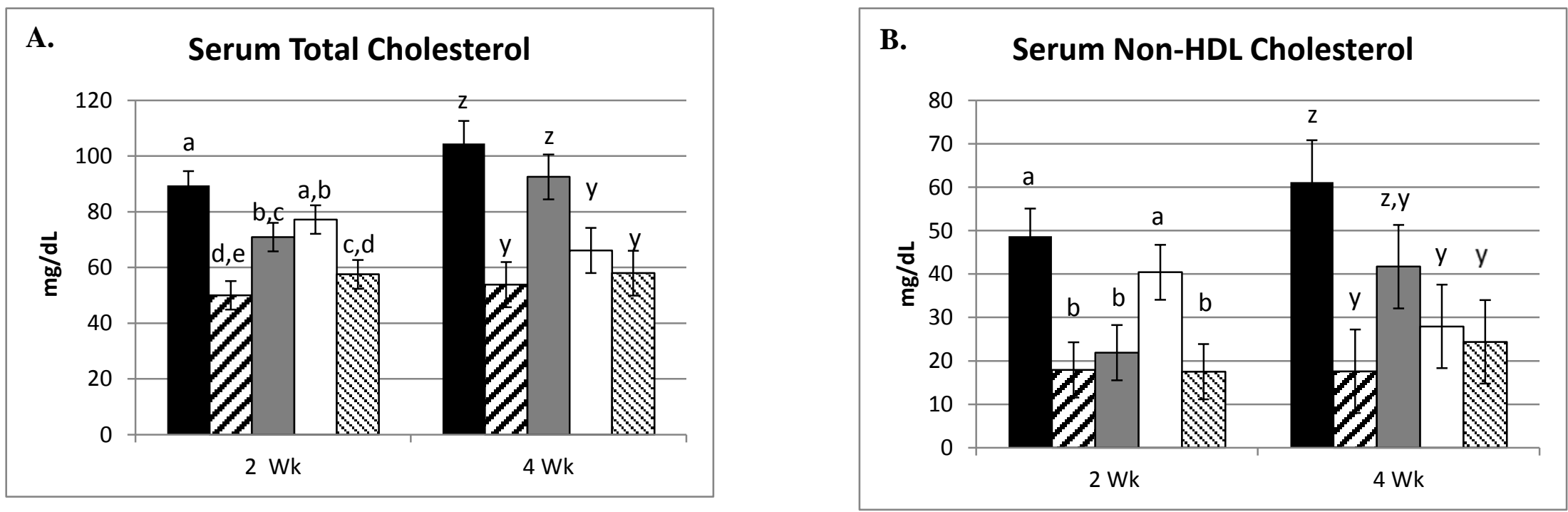
$\square$ SO $\square$ FO $\square$ AO $\square$ YO $\mathbb{N A O + Y O}$
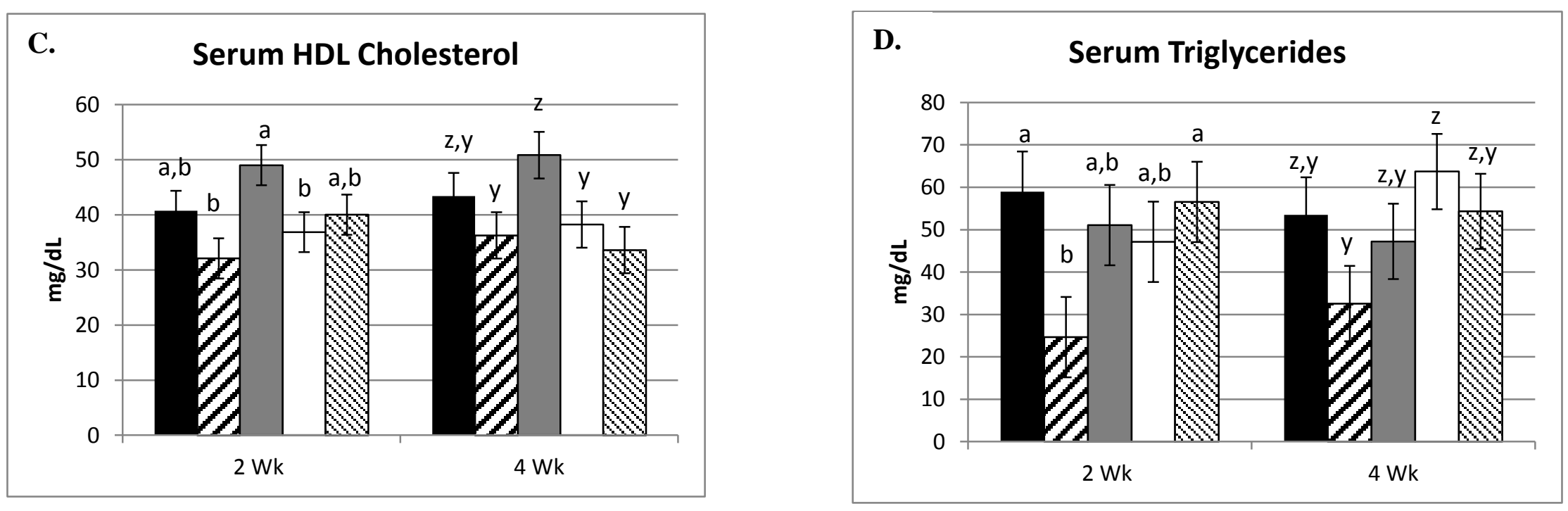
Table 6: Effect of Dietary Treatment on the Fatty Acid Profile of the Liver

\begin{tabular}{|c|c|c|c|c|c|c|c|c|}
\hline & & \multicolumn{5}{|c|}{ Diet $^{2}$} & \multirow[b]{2}{*}{ SEM } & \multirow[b]{2}{*}{ P-Value } \\
\hline Fatty Acid $^{1}$ & Week & SO & FO & AO & YO & $\mathrm{AO}+\mathrm{YO}$ & & \\
\hline \multirow{2}{*}{ C14:0 } & 2 & $0.37^{\mathrm{b}}$ & $0.68^{\mathrm{a}}$ & $0.48^{\mathrm{b}}$ & $0.46^{\mathrm{b}}$ & $0.39^{b}$ & 0.065 & 0.015 \\
\hline & 4 & $0.38^{\mathrm{c}}$ & $0.67^{\mathrm{a}}$ & $0.55^{\mathrm{b}}$ & $0.37^{\mathrm{c}}$ & $0.46^{\mathrm{bc}}$ & 0.041 & $<0.0001$ \\
\hline \multirow{2}{*}{ C16:0 } & 2 & $23.88^{\mathrm{d}}$ & $28.71^{\mathrm{a}}$ & $26.38^{\mathrm{bc}}$ & $24.89^{\mathrm{cd}}$ & $27.91^{\mathrm{ab}}$ & 0.648 & $<0.0001$ \\
\hline & 4 & $22.68^{\mathrm{b}}$ & $30.26^{\mathrm{a}}$ & $26.41^{\mathrm{ab}}$ & $25.79^{b}$ & $24.15^{\mathrm{b}}$ & 1.348 & 0.005 \\
\hline \multirow{2}{*}{ C16:1 } & 2 & $1.12^{\mathrm{b}}$ & $2.63^{\mathrm{a}}$ & $1.01^{\mathrm{b}}$ & $1.09^{b}$ & $1.10^{\mathrm{b}}$ & 0.142 & $<0.0001$ \\
\hline & 4 & $1.51^{\mathrm{b}}$ & $2.90^{\mathrm{a}}$ & $1.30^{\mathrm{b}}$ & $1.29^{b}$ & $1.17^{\mathrm{b}}$ & 0.162 & $<0.0001$ \\
\hline \multirow{2}{*}{ C18:0 } & 2 & 9.03 & 11.61 & 9.74 & 11.36 & 10.86 & 0.710 & 0.068 \\
\hline & 4 & $8.31^{\mathrm{c}}$ & $12.00^{\mathrm{ab}}$ & $9.61^{b c}$ & $10.05^{\mathrm{abc}}$ & $13.02^{\mathrm{a}}$ & 1.055 & 0.023 \\
\hline \multirow{2}{*}{ C18:1 } & 2 & $14.68^{\mathrm{a}}$ & $8.98^{\mathrm{c}}$ & $13.39^{\mathrm{ab}}$ & $12.22^{\mathrm{ab}}$ & $11.94^{b}$ & 0.879 & 0.001 \\
\hline & 4 & $16.36^{\mathrm{a}}$ & $8.55^{\mathrm{d}}$ & $14.54^{\mathrm{ab}}$ & $11.13^{\mathrm{cd}}$ & $11.81^{\mathrm{bc}}$ & 1.055 & $<0.0001$ \\
\hline \multirow{2}{*}{ C18:2 } & 2 & $29.31^{\mathrm{a}}$ & $10.74^{d}$ & $25.88^{b}$ & $26.97^{\mathrm{ab}}$ & $22.66^{c}$ & 0.910 & $<0.0001$ \\
\hline & 4 & $28.57^{\mathrm{a}}$ & $7.93^{c}$ & $25.74^{\mathrm{ab}}$ & $28.05^{\mathrm{a}}$ & $23.20^{b}$ & 1.052 & $<0.0001$ \\
\hline \multirow{2}{*}{ C18:3n-3 } & 2 & $1.37^{\mathrm{a}}$ & $0.85^{\mathrm{b}}$ & $1.07^{\mathrm{ab}}$ & $1.16^{\mathrm{ab}}$ & $0.88^{b}$ & 0.114 & 0.015 \\
\hline & 4 & 4.13 & 0.68 & 1.22 & 1.17 & 0.94 & 1.192 & 0.251 \\
\hline \multirow{2}{*}{ C18:3n-6 } & 2 & $0.22^{\mathrm{ab}}$ & $0.29^{\mathrm{a}}$ & $0.12^{\mathrm{b}}$ & $0.15^{b}$ & $0.092^{\mathrm{b}}$ & 0.044 & 0.020 \\
\hline & 4 & $0.19^{\mathrm{ab}}$ & $0.30^{\mathrm{a}}$ & $0.11^{b}$ & $0.06^{\mathrm{b}}$ & $0.07^{\mathrm{b}}$ & 0.040 & 0.0004 \\
\hline \multirow{2}{*}{ C20:0 } & 2 & 0.34 & 0.34 & 0.31 & 0.36 & 0.30 & 0.103 & 0.992 \\
\hline & 4 & 0.21 & 0.33 & 0.31 & 0.23 & 0.21 & 0.050 & 0.302 \\
\hline \multirow{2}{*}{ C20:1 } & 2 & 0.38 & 0.18 & 0.31 & 0.28 & 0.23 & 0.074 & 0.417 \\
\hline & 4 & 0.28 & 0.10 & 0.23 & 0.26 & 0.14 & 0.069 & 0.302 \\
\hline
\end{tabular}




\begin{tabular}{|c|c|c|c|c|c|c|c|c|}
\hline & & \multicolumn{5}{|c|}{ Diet $^{2}$} & \multirow[b]{2}{*}{ SEM } & \multirow[b]{2}{*}{ P-Value } \\
\hline Fatty Acid $^{1}$ & Week & So & FO & AO & YO & $\mathrm{AO}+\mathrm{YO}$ & & \\
\hline \multirow{2}{*}{ C20:2 } & 2 & 0.37 & 0.37 & 0.31 & 0.33 & 0.26 & 0.078 & 0.398 \\
\hline & 4 & 0.19 & 0.30 & 0.24 & 0.27 & 0.14 & 0.069 & 0.507 \\
\hline \multirow{2}{*}{ C20:3n-6 } & 2 & 1.31 & 1.09 & 1.55 & 1.36 & 1.36 & 0.284 & 0.850 \\
\hline & 4 & $1.30^{\mathrm{a}}$ & $0.40^{\mathrm{b}}$ & $1.51^{\mathrm{a}}$ & $1.41^{\mathrm{a}}$ & $1.28^{\mathrm{a}}$ & 1.275 & $<0.0001$ \\
\hline \multirow{2}{*}{ C20:4 } & 2 & $11.26^{\mathrm{a}}$ & $5.20^{c}$ & $4.49^{\mathrm{cd}}$ & $7.29^{b}$ & $3.74^{\mathrm{d}}$ & 0.458 & $<0.0001$ \\
\hline & 4 & $9.75^{\mathrm{a}}$ & $5.49^{b}$ & $3.57^{\mathrm{c}}$ & $6.21^{\mathrm{b}}$ & $3.14^{\mathrm{c}}$ & 0.494 & $<0.0001$ \\
\hline \multirow{2}{*}{ C20:5 } & 2 & $0.34^{\mathrm{e}}$ & $5.60^{\mathrm{a}}$ & $1.97^{\mathrm{d}}$ & $3.40^{\mathrm{c}}$ & $4.34^{\mathrm{b}}$ & 0.221 & $<0.0001$ \\
\hline & 4 & $1.08^{\mathrm{c}}$ & $6.50^{\mathrm{a}}$ & $2.08^{\mathrm{c}}$ & $4.06^{b}$ & $4.47^{\mathrm{b}}$ & 0.472 & $<0.0001$ \\
\hline \multirow{2}{*}{ C22:5 } & 2 & $0.13^{\mathrm{c}}$ & $1.55^{\mathrm{a}}$ & $0.25^{\mathrm{c}}$ & $1.24^{\mathrm{a}}$ & $0.77^{b}$ & 0.129 & $<0.0001$ \\
\hline & 4 & $0.06^{\mathrm{c}}$ & $1.84^{\mathrm{a}}$ & $0.13^{\mathrm{c}}$ & $1.82^{\mathrm{a}}$ & $0.13^{b}$ & 0.162 & 0.162 \\
\hline \multirow{2}{*}{ C22:6 } & 2 & $5.92^{\mathrm{d}}$ & $21.53^{\mathrm{a}}$ & $12.95^{\mathrm{b}}$ & $7.73^{\mathrm{c}}$ & $13.54^{\mathrm{b}}$ & 0.573 & $<0.0001$ \\
\hline & 4 & $5.14^{\mathrm{e}}$ & $21.82^{\mathrm{a}}$ & $12.63^{\mathrm{c}}$ & $7.87^{\mathrm{d}}$ & $14.90^{b}$ & 0.655 & $<0.0001$ \\
\hline \multirow{2}{*}{ SFA } & 2 & $33.61^{\mathrm{c}}$ & $41.34^{\mathrm{a}}$ & $36.91^{b}$ & $37.08^{b}$ & $39.45^{\mathrm{ab}}$ & 1.111 & 0.0003 \\
\hline & 4 & $31.58^{\mathrm{c}}$ & $43.26^{\mathrm{a}}$ & $36.88^{b}$ & $36.43^{b}$ & $37.85^{\mathrm{b}}$ & 1.652 & 0.0006 \\
\hline \multirow{2}{*}{ MUFA } & 2 & $16.17^{\mathrm{a}}$ & $11.79^{\mathrm{c}}$ & $14.70^{\mathrm{ab}}$ & $13.59^{\mathrm{abc}}$ & $13.27^{\mathrm{bc}}$ & 0.916 & 0.024 \\
\hline & 4 & $18.16^{\mathrm{a}}$ & $11.55^{\mathrm{c}}$ & $16.06^{\mathrm{ab}}$ & $12.68^{\mathrm{c}}$ & $13.12^{\mathrm{bc}}$ & 1.140 & 0.001 \\
\hline \multirow{2}{*}{ PUFA } & 2 & 50.21 & 46.88 & 48.39 & 49.33 & 47.28 & 1.010 & 0.133 \\
\hline & 4 & 50.26 & 45.19 & 47.05 & 50.89 & 49.03 & 1.625 & 0.102 \\
\hline \multirow{2}{*}{ n-3 } & 2 & $10.03^{\mathrm{e}}$ & $30.05^{\mathrm{a}}$ & $17.26^{\mathrm{c}}$ & $13.53^{\mathrm{d}}$ & $20.52^{b}$ & 0.907 & $<0.0001$ \\
\hline & 4 & $11.30^{\mathrm{d}}$ & $32.37^{\mathrm{a}}$ & $16.32^{\mathrm{c}}$ & $15.61^{\mathrm{cd}}$ & $21.55^{b}$ & 1.735 & $<0.0001$ \\
\hline$n-6$ & 2 & $39.82^{\mathrm{a}}$ & $16.67^{\mathrm{e}}$ & $30.82^{\mathrm{c}}$ & $35.46^{b}$ & $26.50^{\mathrm{d}}$ & 1.402 & $<0.0001$ \\
\hline
\end{tabular}




\begin{tabular}{|c|c||c|c|c|c|c|c|c|}
\hline & $\mathbf{4}$ & $38.77^{\mathrm{a}}$ & $12.52^{\mathrm{c}}$ & $30.49^{\mathrm{b}}$ & $35.02^{\mathrm{a}}$ & $27.34^{\mathrm{b}}$ & 1.459 & $<0.0001$ \\
\hline \multirow{2}{*}{$\mathbf{n}-3: \mathbf{n - 6}$} & $\mathbf{2}$ & $0.28^{\mathrm{d}}$ & $1.89^{\mathrm{a}}$ & $0.57^{\mathrm{bc}}$ & $0.38^{\mathrm{cd}}$ & $0.80^{\mathrm{b}}$ & 0.085 & $<0.0001$ \\
\cline { 2 - 9 } & $\mathbf{4}$ & $0.34^{\mathrm{b}}$ & $2.88^{\mathrm{a}}$ & $0.54^{\mathrm{b}}$ & $0.46^{\mathrm{b}}$ & $0.80^{\mathrm{b}}$ & 0.191 & $<0.0001$ \\
\hline
\end{tabular}

${ }^{1}$ Fatty acids from the liver were analyzed by gas chromatography and expressed as a percent of total fatty acids. SFA = saturated fatty acids; MUFA = monounsaturated fatty acids; PUFA = polyunsaturated fatty acids; $\mathrm{n} 3=$ omega-3 fatty acids, $\mathrm{n} 6=$ omega 6 fatty acids, $\mathrm{n} 3: \mathrm{n} 6=$ omega-3 fatty acid to omega- 6 fatty acid ratio.

${ }^{2} \mathrm{SO}=$ soy oil diet $; \mathrm{FO}=$ fish oil diet $; \mathrm{AO}=$ algae oil diet $; \mathrm{YO}=$ yeast oil diet; $\mathrm{AO}+\mathrm{YO}=$ algae oil plus yeast oil diet; SEM $=$ standard error of the mean .

${ }^{\text {abcde }}$ Different letters within a row represent significant differences within week $(\mathrm{p}<0.05)$. 
Figure 5. Effect of Dietary Treatment on mRNA Relative Gene Expression in the Liver - A. acyl-CoA:cholesterol acyltransferase (ACAT), B. apolipoprotein B (ApoB100); C. diglyceride acyltransferase (DGAT); D. low-density lipoprotein receptor (LDLR). E. 3-hydroxy3-methyl-glutaryl-CoA reductase (HMGCR). Data are presented as means \pm SEM. Different letters within week indicate significant differences between treatments $(\mathrm{p}<0.05)$.

SO $Z$ FO $\square$ AO $\square$ YO $\mathbb{A}$ AO+YO
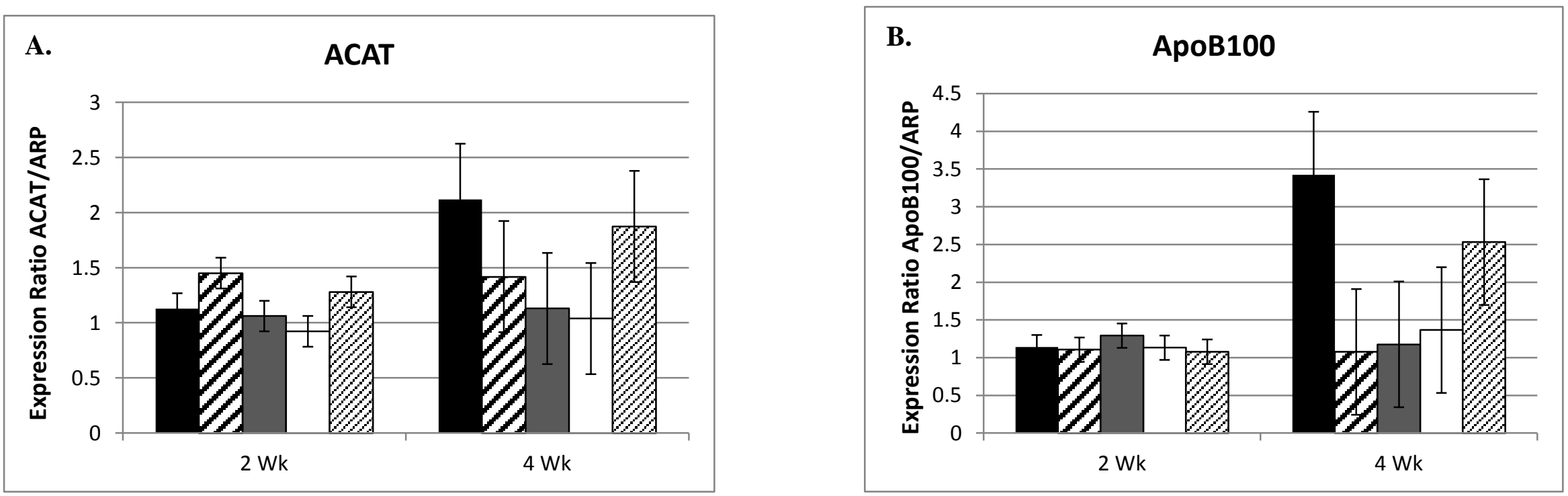
$\square$ SO $\triangle$ FO $\square$ AO $\square$ YO $\mathbb{A}$ AO+YO
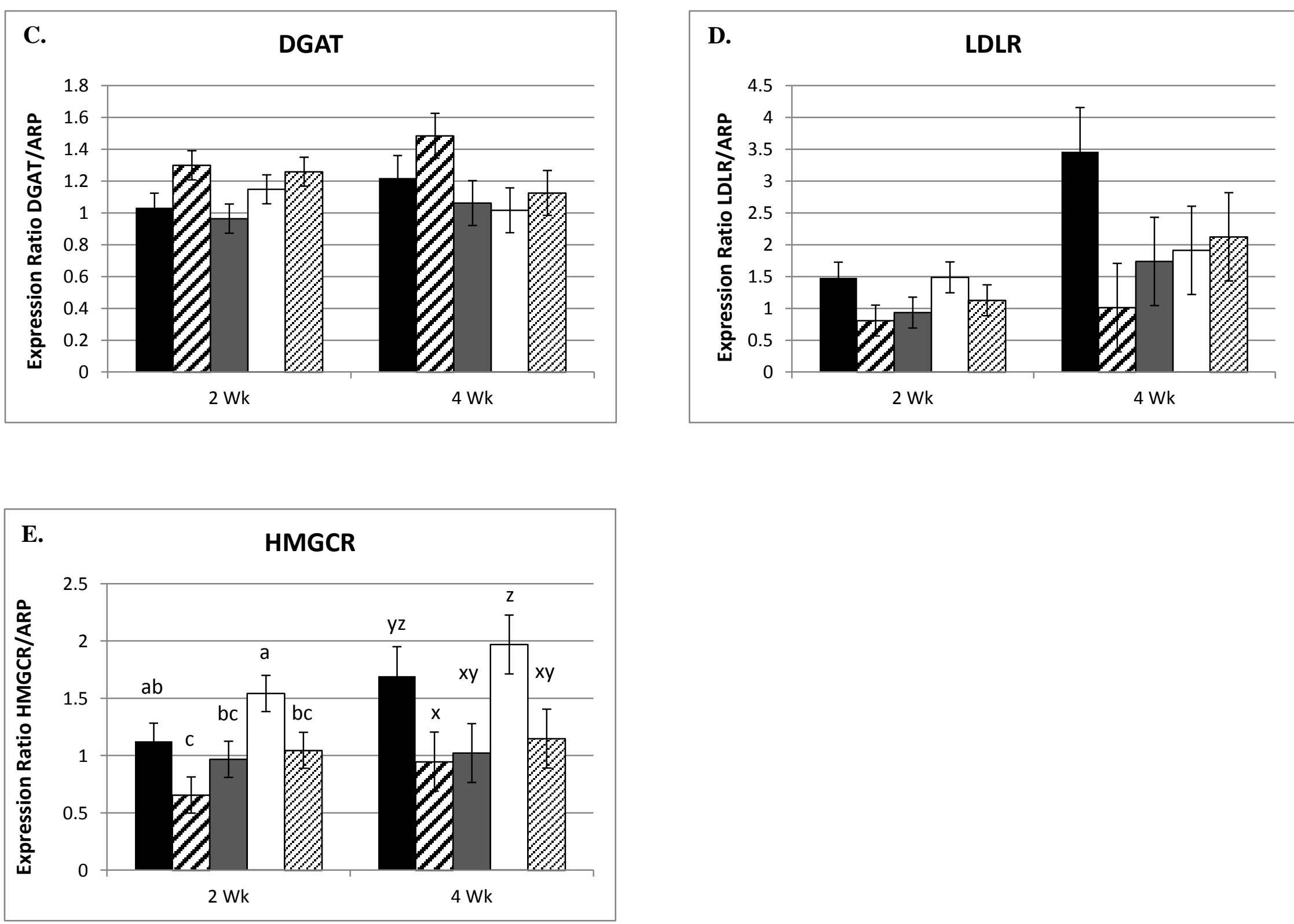


\section{REFERENCES}

1) Kris-Etherton PM, Harris WS, Appel LJ. American Heart Association. Nutrition Committee. 2002. Fish consumption, fish oil, omega-3 fatty acids, and cardiovascular disease. Circulation. 106(21):2747-57.

2) Miniño AM, Arias E, Kochanek KD, Murphy SL, Smith BL. 2002. Deaths: final data for 2000. Natl Vital Stat Rep. 16;50(15):1-119

3) Weitz D, Weintraub H, Fisher E, Schwartzbard A. 2010. Fish Oil for the Treatment of Cardiovascular Disease. Cardiol Rev. 18(5): 258-263.

4) Mahan K, Escott-Stump S. 2008. Krause's Food \& Nutrition Therapy:12 ${ }^{\text {th }} \mathrm{ed}$. W B Saunders Co, St. Louis, MO.

5) Williams CM, Burdge G. 2006. Long-chain n-3 PUFA: plant v. marine sources. Proc Nutr Soc. 65(1):42-50

6) Gropper SS, Smith JL, Groff FL. 2009. Advanced Nutrition and Human Metabolism: $5^{\text {th }}$ ed. Wadsworth, Belmont, CA.

7) Tobert JA. 2003. Lovastatin and beyond: the history of the HMG-CoA reductase inhibitors. Nature Reviews Drug Discovery. 2:517-526.

8) Nelson DL, Cox MM. 2005. Principles of Biochemistry: $4^{\text {th }}$ ed. Freeman and Company, New York, NY.

9) Sampath H, Ntambi JM. 2004. Polyunsaturated fatty acid regulation of gene expression. Nutr Rev. 62:333-339.

10) Eberlé D, Hegarty B, Bossard P, Ferré P, Foufelle F. 2004. SREBP transcription factors: master regulators of lipid homeostasis. Biochimie. 86(11):839-48. 
11) König A, Bouzan C, Cohen JT, Connor WE, Kris-Etherton PM, Gray GM, Lawrence RS, Savitz DA, Teutsch SM. 2005. A quantitative analysis of fish consumption and coronary heart disease mortality. Am J Prev Med. 29(4):335-46.

12) Rokling-Andersen MH, Rustan AC, Wensaas AJ, Kaalhus O, Wergedahl H, Røst TH, Jensen J, Graff BA, Caesar R, Drevon CA. 2009. Marine n-3 fatty acids promote size reduction of visceral adipose depots, without altering body weight and composition, in male Wistar rats fed a high-fat diet. Br J Nutr. 102(7):995-1006.

13) Fickova M, Hubert P, Crémel G, Leray C. 1998. Dietary (n-3) and (n-6) polyunsaturated fatty acids rapidly modify fatty acid composition and insulin effects in rat adipocytes. Journal Of Nutrition. 128(3):512-519.

14) Hill AM, Buckley JD, Murphy KF, Howe PRC. 2007. Combining fish-oil supplements with regular aerobic exercise improves body composition and cardiovascular disease risk factors. Am J Clin Nutr. 5:1267-1274.

15) Mori TA, Burke V, Puddey IB, Watts GF, O'Neal DN, Best JD, Beilin LJ. 2000. Purified eicosapentaenoic and docosahexaenoic acids have differential effects on serum lipids and lipoproteins, LDL particle size, glucose, and insulin in mildly hyperlipidemic men. Am J Clin Nutr. 71(5):1085-94.

16) Grimsgaard S, Bonaa KH, Hansen JB, Nordøy A. 1997. Highly purified eicosapentaenoic acid and docosahexaenoic acid in humans have similar triacylglycerol-lowering effects but divergent effects on serum fatty acids. Am J Clin Nutr. 66(3):649-59.

17) Arai T, Kim H, Chiba H, Matsumoto A. 2009. Anti-obesity effect of fish oil and fish oilfenofibrate combination in female KK mice. Journal Of Atherosclerosis And Thrombosis. 16(5):674-683. 
18) Ryan AS, Keske MA, Hoffman JP, Nelson EB. 2009. Clinical overview of algaldocosahexaenoic acid: effects on triglyceride levels and other cardiovascular risk factors. Am J Therapy. 16(2):183-92.

19) Pietrofesa RA, Azain MJ, Barnes KM. 2010. Lipidemic and cholesterolemic effects of feeding an algal source of docosahexaenoic acid to mice. FASEB J. 24:Abst\#939.8.

20) Shelton AG, Pietrofesa RA, Barnes KM. 2011. Effect of high docosahexaenoic acid-algal oil on body fat and serum lipids in mice. FASEB J. 25:Abst\#586.5.

21) Conquer JA, Holub BJ. 1996. Supplementation with an algae source of docosahexaenoic acid increases (n-3) fatty acid status and alters selected risk factors for heart disease in vegetarian subjects. J Nutr. 126(12):3032-9.

22) Belcher LA, MacKenzie SA, Donner M, Sykes GP, Frame SR, Gillies PJ. 2011. Safety assessment of EPA-rich triglyceride oil produced from yeast: genotoxicity and 28-day oral toxicity in rats. Reg Toxic and Pharm. 59(1):53-63.

23) MacKenzie SA, Belcher LA, Sykes GP, Frame SR, Mukerji P, Gillies PJ. 2010. Safety assessment of EPA-rich oil produced from yeast: Results of a 90-day subchronic toxicity study. Regul Toxicol Pharmacol. 58(3):490-500.

24) Bligh EG, Dyer WJ. 1959. A rapid method of total lipid extraction and purification. Can J Biochem Phys. 37: 911-917.

25) Park PW, Goins RE. 1994. In Situ Preparation of Fatty Acid Methyl Esters for Analysis of Fatty Acid Composition in Foods. Journal of Food Science, 59: 1262-1266.

26) Shelton VJ, Shelton AG, Azain MJ, Hargrave-Barnes KM. 2012. Incorporation of conjugated linoleic acid into brain lipids is not necessary for conjugated linoleic acidinduced reductions in feed intake or body fat in mice. Nutr Res. 32(11):827-36. 
27) Barnes KM, Winslow NR, Shelton AG, Hlusko KC, Azain MJ. 2012. Effect of dietary conjugated linoleic acid on marbling and intramuscular adipocytes in pork. J Anim Sci. 90(4):1142-9.

28) Peirson SN, Butler JN, Foster RG. 2003. Experimental validation of novel and conventional approaches to quantitative real-time PCR data analysis. Nucleic Acids Res. 31(14):e73.

29) Pfaffl MW. 2001. A new mathematical model for relative quantification in real-time RTPCR. Nucleic Acids Res. 29(9):e45.

30) Tou JC, Altman SN, Gigliotti JC, Benedito VA, Cordonier EL. 2011. Different sources of omega-3 polyunsaturated fatty acids affects apparent digestibility, tissue deposition, and tissue oxidative stability in growing female rats. Lipids Health Dis. 10:179.

31) Reddy JK, Rao MS. 2006. Lipid metabolism and liver inflammation. II. Fatty liver disease and fatty acid oxidation. Am. J. Physiol. Gastrointest. Liver Physiol. 290 (5): G852-8.

32) Harris WS, Bulchandani D. 2006. Why do omega-3 fatty acids lower serum triglycerides? Curr Opin Lipidol. 17(4):387-93.

33) Kaur G, Sinclair AJ, Cameron-Smith D, Barr DP, Molero-Navajas JC, Konstantopoulos N. 2011. Docosapentaenoic acid (22:5n-3) down-regulates the expression of genes involved in fat synthesis in liver cells. Prostaglandins Leukot Essent Fatty Acids. 85(34):155-61.

34) Hromadová M, Seböková E, Klimeś I. 1994. HMG-CoA reductase activity in the liver of rats with hereditary hypertriglyceridemia: effect of dietary fish oil. Endocr Regul. 28(4):211-4. 
35) Yang ZH, Miyahara H, Takeo J, Hatanaka A, Katayama M. 2011. Pollock oil supplementation modulates hyperlipidemia and ameliorates hepatic steatosis in mice fed a high-fat diet. Lipids Health Dis. 25;10:189.

36) Brown AM, Gibbons GF. 1997. The effect of ACAT inhibition on VLDL secretion in rats fed a diet rich in fish-oil. Biochem Soc Trans. 25(4):S688.

37) Botham KM, Zheng X, Napolitano M, Avella M, Cavallari C, Rivabene R, Bravo E. 2003. The effects of dietary n-3 polyunsaturated fatty acids delivered in chylomicron remnants on the transcription of genes regulating synthesis and secretion of very-lowdensity lipoprotein by the liver: modulation by cellular oxidative state. Exp Biol Med (Maywood). 228(2):143-51.

38) al-Shurbaji A, Larsson-Backström C, Berglund L, Eggertsen G, Björkhem I. 1991. Effect of n-3 fatty acids on the key enzymes involved in cholesterol and triglyceride turnover in rat liver. Lipids. 26(5):385-9.

39) Deckelbaum RJ, Worgall TS, Seo T. 2006. n-3 fatty acids and gene expression. Am J Clin Nutr. 83(6 Suppl):1520S-1525S.

40) Gillingham LG, Harris-Janz S, Jones PJ. 2011. Dietary monounsaturated fatty acids are protective against metabolic syndrome and cardiovascular disease risk factors. Lipids. 46(3):209-28.

41) Simopoulos AP. 2002. The importance of the ratio of omega-6/omega-3 essential fatty acids. Biomed Pharmacother. 56(8):365-79. 